\title{
GEOHYDROLOGIC FRAMEWORK OF THE SNAKE RIVER PLAIN REGIONAL AQUIFER SYSTEM, IDAHO AND EASTERN OREGON
}

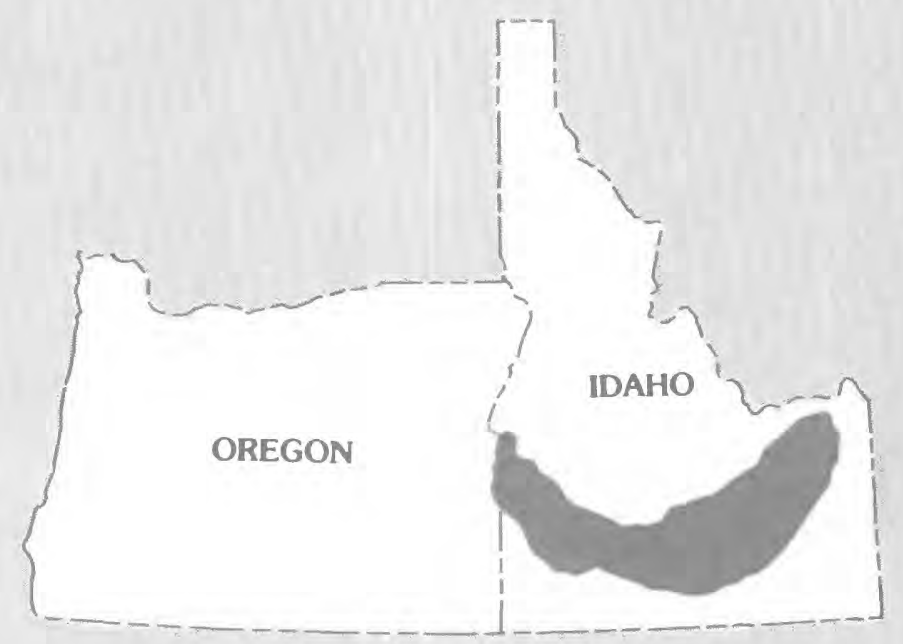




\section{Geohydrologic Framework}

of the Snake River Plain

Regional Aquifer System,

\section{Idaho and Eastern Oregon}

By R.L. WHITEHEAD

REGIONAL AQUIFER-SYSTEM ANALYSIS-SNAKE RIVER PLAIN, IDAHO

U.S. GEOLOGICAL SURVEY PROFESSIONAL PAPER 1408-B

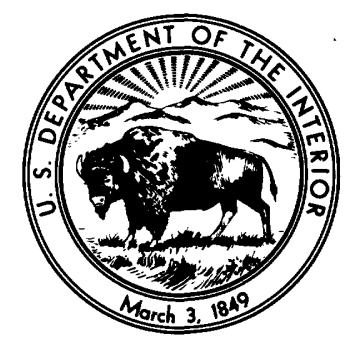




\section{U.S. DEPARTMENT OF THE INTERIOR}

MANUEL LUJAN, JR., Secretary

\section{U.S. GEOLOGICAL SURVEY}

Dallas L. Peck, Director

Any use of trade, product, or firm names in this publication

is for descriptive purposes only and does not imply endorsement

by the U.S. Government

\section{Library of Congress Cataloging-in-Publication Data}

Whitehead, R.L.

Geohydrologic framework of the Snake River Plain regional aquifer system, Idaho and eastern Oregon / by R.L. Whitehead.

p. cm. - (Regional aquifer system analysis-Idaho and eastern Oregon) (U.S. Geological Survey professional paper ; 1408-B)

Includes bibliographical references.

1. Aquifers-Snake River Plain (Idaho and Or.) I. Title. II. Series. III. Series: U.S. Geological Survey professional paper ; 1408-B.

GB1199.3.S63W45 1991

$551.49^{\prime} 09796$ ' 1 -dc20

For sale by the Books and Open-File Reports Section, U.S. Geological Survey, Federal Center, Box 25425, Denver, CO 80225 


\section{FOREWORD}

\section{THE REGIONAL AQUIFER-SYSTEM ANALYSIS PROGRAM}

The Regional Aquifer-System Analysis (RASA) Program was started in 1978 following a congressional mandate to develop quantitative appraisals of the major ground-water systems of the United States. The RASA Program represents a systematic effort to study a number of the Nation's most important aquifer systems, which in aggregate underlie much of the country and which represent an important component of the Nation's total water supply. In general, the boundaries of these studies are identified by the hydrologic extent of each system and accordingly transcend the political subdivisions to which investigations have often arbitrarily been limited in the past. The broad objective for each study is to assemble geologic, hydrologic, and geochemical information, to analyze and develop an understanding of the system, and to develop predictive capabilities that will contribute to the effective management of the system. The use of computer simulation is an important element of the RASA studies, both to develop an understanding of the natural, undisturbed hydrologic system and the changes brought about in it by human activities, and to provide a means of predicting the regional effects of future pumping or other stresses.

The final interpretive results of the RASA Program are presented in a series of U.S. Geological Survey Professional Papers that describe the geology, hydrology, and geochemistry of each regional aquifer system. Each study within the RASA Program is assigned a single Professional Paper number, and where the volume of interpretive material warrants, separate topical chapters that consider the principal elements of the investigation may be published. The series of RASA interpretive reports begins with Professional Paper 1400 and thereafter will continue in numerical sequence as the interpretive products of subsequent studies become available.

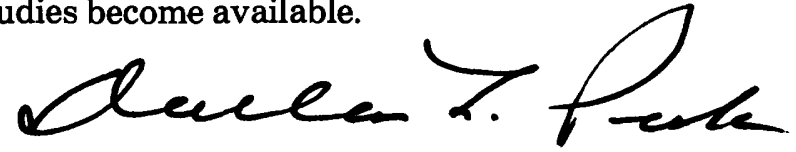

Dallas L. Peck Director 



\title{
CONTENTS
}

\begin{tabular}{|c|c|c|}
\hline & Page & \\
\hline 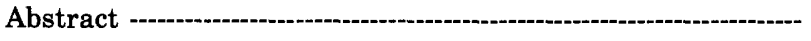 & B1 & Areal distribution and description of rocks-Continued \\
\hline Introduction --- & 1 & Younger alluvium - - \\
\hline Purpose and scope & 3 & Application of surface geophysical methods to subsurface \\
\hline Previous studies & 3 & hydrogeologic mapping - \\
\hline Acknowledgments & 4 & Electrical resistivity surveys - \\
\hline Well-numbering system & 4 & Gravity modeling \\
\hline Geologic history - & 4 & Areal extent and lithology of the Snake River Plain regional \\
\hline Origin of the Snake River Plain - & 6 & aquifer system - \\
\hline Structure - - & 6 & Western plain \\
\hline Stratigraphy & 7 & Eastern plain - \\
\hline Areal distribution and description of rocks -- & 8 & Hydraulic characteristics of Quaternary basalt and alluvial \\
\hline Older silicic volcanic rocks -------- & 9 & 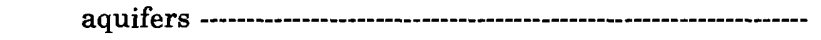 \\
\hline Older basalt --.-1- & 9 & Geologic controls on ground-water movement --- \\
\hline Older alluvium ---1- & 10 & Quaternary basalt aquifers \\
\hline Younger silicic volcanic rocks - - & 11 & Tertiary silicic volcanic and basalt aquifers --------- \\
\hline Younger basalt ---1-1 & 11 & Summary -- \\
\hline Windblown deposits - & 16 & References cited - \\
\hline
\end{tabular}

\section{ILLUSTRATIONS}

\author{
[Plates are in pocket]
}

Plate 1. Generalized geologic map of the Snake River basin, Idaho and eastern Oregon.

2. Generalized geologic profiles of the north wall of the Snake River canyon from King Hill to Milner, Snake River Plain, Idaho and eastern Oregon.

3. Map showing thickness of Quaternary basalt and geologic cross sections $B-B$ ' through $J-J$, Snake River Plain, Idaho and eastern Oregon.

4. Map showing depth to uppermost volcanic unit and structure contours of top of uppermost volcanic unit, Snake River Plain, Idaho and eastern Oregon.

5. Map showing total thickness of sedimentary rocks, Snake River Plain, Idaho and eastern Oregon.

6. Map showing electrical resistivity profiles $K-K$ through $W-W$, Snake River Plain, Idaho and eastern Oregon.

FigURE 1. Map showing location of study area - B2

2. Diagram showing well-numbering system -

3. Geologic cross section $A-A^{\prime}$, western Snake River Plain - 7

4. Lithologic log of RASA test hole 7S-15E-12CBA1 - 9

5. Photograph and diagram showing zonation in a typical flow of basalt of the Snake River Group --an

6. Diagram showing flow units and cooled units in basalt of the Snake River Group -

7. Photographs showing surficial features of basalt of the Snake River Group -

8. Map showing Bouguer gravity anomaly contours, locations of modeled sections, and gravity models $X-X$ through $E E-E E^{\prime}$

9. Map showing percentage of coarse-grained sedimentary rocks in upper $200 \mathrm{ft}$ of the western Snake River Plain regional aquifer system -

10. Schematic cross section showing relation of fine- and coarse-grained sedimentary rocks, western Snake River Plain

11. Map showing estimated transmissivity in the eastern Snake River Plain based on digital modeling ---

12. Diagram showing effect of dense basalt layers on ground-water levels in a hypothetical flow of basalt of the Snake River Group

13. Diagram showing effects of atmospheric pressure changes on air movement in the unsaturated zone -

14. Graph showing effects of atmospheric pressure changes on water level in well 8S-23E-2BA1 


\section{TABLES}

\section{CONVERSION FACTORS AND ABBREVIATIONS}

For readers who wish to convert measurements from the inch-pound system of units to the metric system of units, the conversion factors are listed below:

\begin{tabular}{rcl}
\hline Multiply inch-pound unit & By & To obtain metric unit \\
\hline acre & 4,047 & square meter $\left(\mathrm{m}^{2}\right)$ \\
cubic foot per second $\left(\mathrm{ft}^{3} / \mathrm{s}\right)$ & 0.02832 & cubic meter per second $\left(\mathrm{m}^{3} / \mathrm{s}\right)$ \\
foot $(\mathrm{ft})$ & 0.3048 & meter $(\mathrm{m})$ \\
foot squared per day $\left(\mathrm{ft}^{2} / \mathrm{d}\right)$ & 0.0929 & meter squared per day $\left(\mathrm{m}^{2} / \mathrm{d}\right)$ \\
gallon per minute $(\mathrm{gal} / \mathrm{min})$ & 0.06309 & liter per second $(\mathrm{L} / \mathrm{s})$ \\
inch $(\mathrm{in})$. & 25.40 & millimeter $(\mathrm{mm})$ \\
mile $(\mathrm{mi})$ & 1.609 & kilometer $(\mathrm{km})$ \\
pound per cubic foot $\left(\mathrm{lb} / \mathrm{ft}^{3}\right)$ & 0.016 & gram per cubic centimeter $\left(\mathrm{g} / \mathrm{cm}^{3}\right)$ \\
square mile $\left(\mathrm{mi}^{2}\right)$ & 2.590 & square kilometer $\left(\mathrm{km}^{2}\right)$ \\
\hline
\end{tabular}

\section{SEA LEVEL}

In this report, "sea level" refers to the National Geodetic Vertical Datum of 1929 (NGVD of 1929) - a geodetic datum derived from a general adjustment of the first-order level net of both the United States and Canada, formerly called "Sea Level Datum of 1929." 


\title{
GEOHYDROLOGIC FRAMEWORK OF THE SNAKE RIVER PLAIN REGIONAL AQUIFER SYSTEM, IDAHO AND EASTERN OREGON
}

\author{
By R.L. WHITEHEAD
}

\begin{abstract}
The Snake River Plain in southern Idaho is a major geologic structure of uncertain origin. Surface geology is generally well defined, but subsurface geology is poorly defined below about 500 feet. Rocks that underlie the plain form the framework for a regional ground-water system that supplies large quantities of water for irrigation and makes the plain nationally important in terms of agricultural production.

The 15,600-square-mile Snake River Plain is a grabenlike structure that formed in middle Miocene time. The graben may have been formed by oblique extensional forces resulting from interactions between the North American and Pacific tectonic plates. The oldest known rocks underlying the plain, penetrated in a 14,007-foot-deep test hole northwest of Boise, are of middle Miocene age. Miocene volcanic rocks at the plain's margin that dip toward and underlie the plain were highly faulted and severely eroded before the plain was formed.

Faults along the margins of the eastern part of the plain are not visible at land surface and have been defined chiefly by geophysical methods. However, well-defined fault systems bound the western part of the plain.

The eastern plain is underlain predominantly by Quaternary basalt of the Snake River Group, which is intercalated with sedimentary rocks along the margins. Basalt crops out or is less than 10 feet below land surface in the central part of the eastern plain and is usually less than 100 feet below land surface elsewhere. Geophysical data and drillers' logs indicate that Quaternary basalt in the central part of the eastern plain is as much as 5,000 feet thick. A test hole about 10 miles northeast of the Snake River near Wendell provided the first information about deep subsurface stratigraphic relations in that part of the plain. The stratigraphic sequence penetrated in the test hole is similar to that in the north wall of the Snake River canyon between Milner and King Hill. In that area, basalt of the Snake River Group thins toward the river and is underlain by sedimentary rocks and basalt of the Tertiary and Quaternary Idaho Group.

The western plain is underlain mainly by unconsolidated and weakly consolidated Tertiary and Quaternary sedimentary rocks as much as 5,000 feet thick. Basalt also is present in the western plain and is most extensive near Mountain Home.

Quaternary basalt of the Snake River Group, which composes much of the Snake River Plain regional aquifer system, is highly transmissive. In the eastern plain, a thick sequence of thinlayered basalt flows yields large volumes of water to wells. Wells open to less than 100 feet of the aquifer yield as much as 7,000 gallons per minute; yields of 2,000 to 3,000 gallons per minute with only a few feet of drawdown are common. Transmissivity
\end{abstract}

commonly exceeds 100,000 feet squared per day and, in places, 1 million feet squared per day.

Large springs in the Snake River canyon between Milner and King Hill issue at the contact between highly transmissive pillow lava and less transmissive underlying rocks. In 1980, ground-water discharge between Milner and King Hill, largely spring flow, averaged about 6,000 cubic feet per second.

In the western plain, coarse-grained sedimentary deposits are thickest and transmissivity is highest along the northern margins. The percentage of coarse-grained sedimentary deposits decreases to the southwest, where lacustrine sedimentary deposits predominate.

In most of the eastern plain, the upper part of the groundwater system is unconfined. At depth and in much of the western plain, aquifers are confined.

Across most of the plain, Quaternary basalt aquifers overlie aquifers in the Tertiary Idavada Volcanics and Banbury Basalt of the Idaho Group. The older volcanic rocks are typically much less transmissive than the Quaternary basalt. Faults and fractures are permeable zones for water storage and conduits for water movement. In places near the margins of the plain, the Idavada Volcanics contains important geothermal aquifers.

\section{INTRODUCTION}

The Snake River Plain is an arcuate area of $15,600 \mathrm{mi}^{2}$ (fig. 1) that extends across southern Idaho into easternmost Oregon. The plain ranges from about 30 to $70 \mathrm{mi}$ in width and from 2,100 to $6,000 \mathrm{ft}$ in altitude above sea level. The relatively flat plain slopes generally westward and is surrounded by high mountains that range from 7,000 to $12,000 \mathrm{ft}$ in altitude. The Snake River, the main stream draining the area, enters eastern Idaho from Wyoming and generally follows the southern edge of the plain. The Snake River is one of the steepest large rivers in North America (Malde, 1968, p. 6). In places, the river is entrenched as much as $700 \mathrm{ft}$ below the surface of the plain.

Areal extent of the Snake River Plain, as defined in this study, is based on geology and topography. Generally, the boundary of the plain is at the land-surface contact between the Tertiary and older rocks that border the plain and the Quaternary sedimentary and 


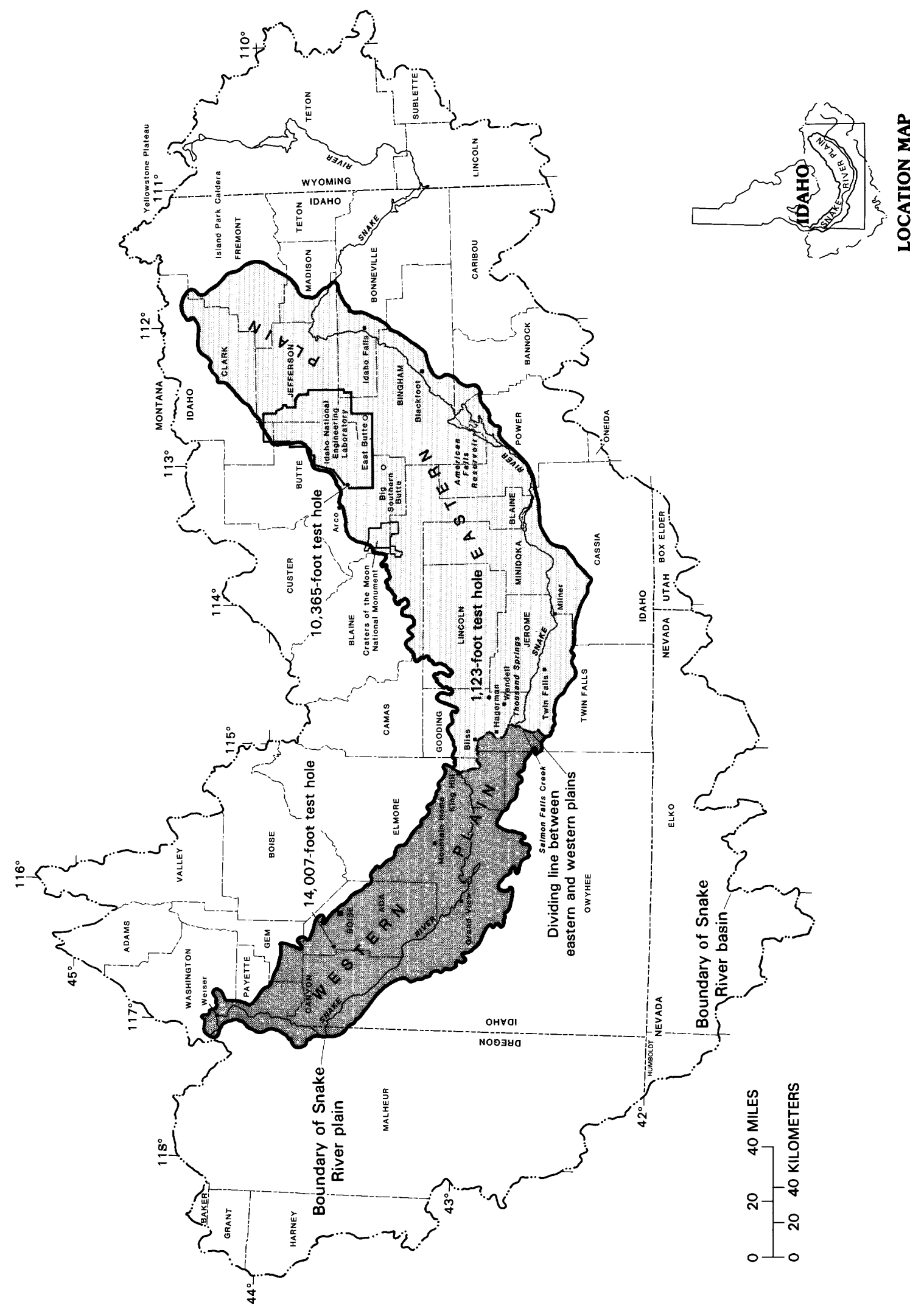


volcanic rocks that underlie the plain. In some areas, an arbitrary boundary was selected on the basis of topographic relief, even though the younger rocks extend beyond the boundary.

Distinct changes in geology and hydrology near King Hill make feasible a geohydrologic division of the plain into eastern and western parts (fig. 1). The line separating the two parts is a drainage divide from the northern boundary of the plain to the Snake River at King Hill, the Snake River upstream to Salmon Falls Creek, and Salmon Falls Creek to the southern boundary of the plain. The eastern plain is $10,800 \mathrm{mi}^{2}$; the western plain is $4,800 \mathrm{mi}^{2}$.

Agriculture and its related activities dominate the economy of the plain. In 1980, more than 3 million acres were irrigated. Of this area, nearly 1 million acres were supplied by ground water (Lindholm and Goodell, 1986). Ground water also is the source for most municipal, industrial, and domestic supplies.

\section{PURPOSE AND SCOPE}

The U.S. Geological Survey's Snake River Plain Regional Aquifer-System Analysis (RASA) study began in October 1979. The purposes of the study (Lindholm, 1981) were to (1) refine knowledge of the regional ground-water-flow system, (2) determine effects of conjunctive use of ground and surface water, and (3) describe water chemistry. To accomplish these goals, the study was divided into subprojects to (1) define the geohydrologic framework, (2) determine the hydrologic budget, (3) define the water chemistry, (4) determine water use, and (5) develop digital ground-water-flow models of the eastern and western parts of the plain.

Lindholm (1981) presented a plan of study for the Snake River Plain regional aquifer study. Preliminary interpretative reports generated by the RASA study to date (1986) include (1) a regional water-table map and description of the groundwater-flow system (Lindholm and others, 1983 and 1986); (2) a description of the geohydrologic framework (Whitehead, 1986b); (3) water budgets and flow in the Snake River (Kjelstrom, 1986); (4) water withdrawals for irrigation (Bigelow and others, 1984); (5) a map of land use showing irrigated acreage (Lindholm and Goodell, 1986); (6) a description of surface- and ground-water quality (Low, 1985); and (7) a ground-water-flow model of the eastern Snake River Plain (Garabedian, 1986).

Final interpretative results of the Snake River Plain RASA study are presented in Professional Paper 1408, which consists of seven chapters as follows:
Chapter A is a summary of the aquifer system.

Chapter B (this report) describes the geohydrologic framework, hydraulic properties of rocks composing the framework, and geologic controls on ground-water movement.

Chapter $\mathrm{C}$ describes ground-water/surface-water relations and ground-water budgets.

Chapter D describes solute geochemistry of the cold-water and geothermal-water systems.

Chapter E describes water use.

Chapter F describes results of ground-water-flow modeling of the eastern Snake River Plain.

Chapter G describes results of ground-water-flow modeling of the western Snake River Plain.

\section{PREVIOUS STUDIES}

General geologic features of part of the eastern Snake River Plain were described briefly by Hayden (1872) during a geologic reconnaissance of Montana and adjacent territories. The first information on ground water was given by Lindgren (1898), who described the geology and water resources of the Boise quadrangle in the western part of the Snake River Plain.

Russell (1902, 1903a, b) described the geology of the entire Snake River Plain in detail. He also described many of the large springs in the Snake River canyon in his 1902 report. His 1903 reports describe the geology and artesian basins of southeastern Oregon and southwestern Idaho. Lindgren and Drake (1904a, b) described the geology and water resources of the Nampa and Silver City quadrangles in southwestern Idaho.

Mansfield (1920, 1927, 1929) described geology and mineral resources of southeastern Idaho, including part of the Snake River Plain. Water resources are discussed in some detail in Mansfield's 1920 report, but are mentioned only briefly in his 1927 and 1929 reports. A preliminary report by Stearns and Bryan (1925) describes the geology and water resources of the Mud Lake area in the northeastern part of the Snake River Plain. A 1938 report by Stearns and others was the first comprehensive report on water resources of the eastern Snake River Plain. A 1939 report by Stearns and others is the completion report of the earlier (1925) study by Stearns and Bryan.

Mundorff and others (1964) described the water resources of the entire Snake River Plain, with emphasis on use of ground water for irrigation. Norvitch and others (1969) used a transient state, electric analog model to study effects of artificial recharge on the eastern Snake River Plain regional aquifer system. 
Crosthwaite $(1973,1974)$ described the results of test drilling and ground-water investigations in parts of the Snake River Plain. Mantei (1974) described an electric analog study, and deSonneville (1974) and Newton (1978) conducted digital model studies of the eastern Snake River Plain. Numerous local studies, most of which are listed in the references, have been conducted in parts of the plain.

Results of many more recent geophysical and geologic studies of the Snake River Plain are presented in a single volume that describes the Cenozoic geology of Idaho (Bonnichsen and Breckenridge, 1982).

\section{ACKNOWLEDGMENTS}

The assistance of many people made possible the completion of this part of the RASA study and is gratefully acknowledged. Special thanks are given to Spencer Wood, Boise State University; Gordon Haskett and Loren Hampton, U.S. Bureau of Reclamation; Jack Barraclough and Barney Lewis, U.S. Geological Survey, Idaho National Engineering Laboratory; and H.R. Covington and H.E. Malde, U.S. Geological Survey, Geologic Division.

Mineralogic and chemical identification of rocks from the project test hole was made by P.P. Hearn and B.A. Scott, U.S. Geological Survey, Geologic Division, and W.W. Wood, U.S. Geological Survey, Water Resources Division. Their assistance is greatly appreciated.

\section{WELL-NUMBERING SYSTEM}

The well-numbering system (fig. 2) used by the U.S. Geological Survey in Idaho indicates the location of wells within the official rectangular subdivision of the public lands, with reference to the Boise base line and Meridian. The first two segments of the number designate the township (north or south) and range (east or west). The third segment gives the section number; three letters follow which indicate, respectively, the $1 / 4$ section (160acre tract), $1 / 4-1 / 4$ section ( 40 -acre tract), and $1 / 4-1 / 4-$ $1 / 4$ section (10-acre tract); last is the serial number of the well within the tract.

Quarter sections are lettered A, B, C, and D in counterclockwise order from the northeast quarter of each section. Within the quarter sections, 40-acre and 10-acre tracts are lettered in the same manner. Thus, well $7 \mathrm{~S}-15 \mathrm{E}-12 \mathrm{CBA} 1$ is in the $\mathrm{NE}^{1 / 4} \mathrm{NW}^{1 / 4} \mathrm{SW}^{1 / 4}$ sec. 12 , T. 7 S., R. 15 E., and was the first well inventoried in that tract.

\section{GEOLOGIC HISTORY}

Much of the following brief geologic history of southern Idaho and adjacent States was modified from Ross and Forrester (1958, p. 29-36).

Marine sedimentation predominated during much of the Paleozoic Era; however, gentle crustal disturbances caused uplift during much of the late Paleozoic Era. Deposition resumed thereafter and continued throughout the Mesozoic Era, during which igneous activity and extensive, violent crustal movements were common. During the Cretaceous Period, the Idaho batholith intruded indurated Paleozoic and Mesozoic rocks and thrust them as much as $50 \mathrm{mi}$ eastward. Uplift continued until the early Cenozoic Era, when erosion became prevalent. After a long interval of erosion, renewed uplift again created a rugged, mountainous terrain. Eruption of the Challis Volcanics of Eocene age began about 51 million years ago (McIntyre and others, 1982, p. 3) and lasted about 11 m.y. Challis lava flows were areally extensive and nearly filled many valleys. Toward the end of this eruptive period, ash flows predominated. A period of erosion followed, resulting in a subdued topography before Miocene volcanic activity began.

Rocks referred to in this report as older silicic volcanic rocks and older basalts were extruded during the Miocene Epoch. They covered much of the Snake River Plain area, particularly the southern and western parts. Most of the area north and west of the plain has been free of volcanic activity since Miocene time. Miocene volcanic rocks were deformed and eroded before later volcanic activity and formation of the Snake River Plain.

Unknown forces associated with Miocene volcanic activity created the depression now referred to as the Snake River Plain (Leeman, 1982, p. 156; Mabey, 1982 , p. 150). Following structural formation of the plain, volcanic activity resumed and continued into the Holocene. Basaltic lava of the Tertiary Snake River Group was the last extruded material; the latest eruption was about 2,000 years ago. Concurrent with volcanism, sediment derived largely from mountains bordering the plain was deposited as layers intercalated with the basalt. The plain continued to subside as a result of loading from extruded lava and sedimentary deposits and from weakening of the crust as lava was removed from underground magma chambers. The base of Cenozoic rocks is now 


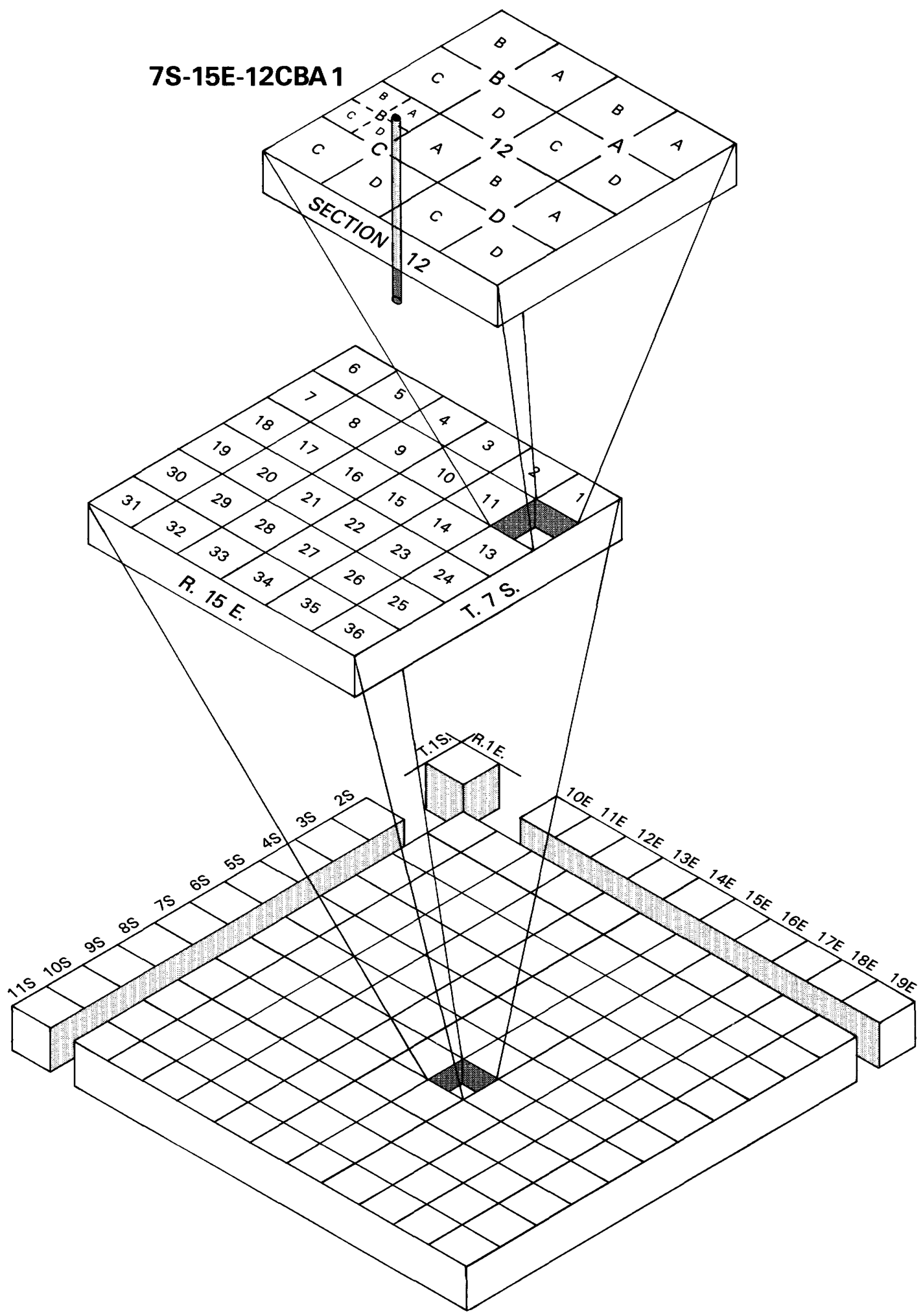

Figure 2.-Well-numbering system. 
thousands of feet below sea level, particularly in the western part of the Snake River Plain.

\section{ORIGIN OF THE SNAKE RIVER PLAIN}

Postulations about the origin of the Snake River Plain involve both volcanism and tectonism. The surface of the plain displays a variety of volcanic features, such as cinder cones, craters, shield volcanoes, and lava flows, that attest to its geologic youth. Holocene volcanism, open fissures, and evidence of continued subsidence show that the plain is an actively developing structure (Mabey, 1982, p. 150). Investigators have proposed a variety of theories concerning the formation of the plain, no one of which takes into account all known geological and geophysical information (Robertson and others, 1974, p. 36). However, most investigators agree that development of the plain began in middle Miocene time (Christiansen and McKee, 1978, p. 287).

The Snake River Plain has been described as a depression, downwarp, graben, and rift. Early investigators Lindgren (1898) and Russell (1902) recognized that northwest-trending faults bounding the western plain suggest that it is a graben. On the basis of the plainward dip of rocks along the margins, they also recognized that downwarping had occurred. Downwarping has played a definite part in the plain's formation, if only as a reaction to other crustal movements. The theory that the entire plain is a major rift (Hamilton and Myers, 1966) cannot be totally satisfied with the current information, which is based mainly on geophysical data (Robertson and others, 1974, p. 36). On the basis of surface geology and geophysical anomalies, Mabey (1982, p. 140) discussed the plain as three separate units-the northwesttrending western Snake River Plain, the northeasttrending eastern Snake River Plain, and the central Snake River Plain. The western and central parts of the plain may have similar origins and may be termed grabens or rifts. On the basis of gravity anomaly relations, however, they differ from typical continental grabens or rifts (Mabey, 1982, p. 145). The Snake River Plain also may be related to the regional rift that extends through northern Nevada and that developed as a response to regional west-southwest extensional forces. The eastern Snake River Plain appears to have formed by different forces, such as a response to extension normal to the plain's axis. The eastern plain also may be the track of an eastwardmigrating thermal anomaly now centered in the geologically active Yellowstone Plateau region (Mabey, 1982 , p. 150).
The thermal or hot spot theory concerning the origin of the Snake River Plain was proposed by Morgan (1972) and was discussed most recently by Leeman (1982, p. 155). A migration of rhyolitic volcanism from west (about $17 \mathrm{~m} . \mathrm{y}$. old) to east (about 0.07 m.y. old) resulted in 1.2 to $1.6 \mathrm{in}$./yr of longitudinal movement along the axis of the plain. The location of inferred regional and local stress fields and geophysical evidence from large-scale reconstitution of crustal rock tend to support the theory of the North American tectonic plate passing over a permanent, deep-rooted hot spot currently under the Yellowstone Plateau. Christiansen and McKee (1978, p. 299-304) discussed an alternative theory based on a volcanotectonic evolution model and related forces associated with the North American and Pacific plates. They stated (p. 304):

The High Lava Plains [includes the Snake River Plain] are a transitional transform boundary zone of the Great Basin*** [The] model emphasizes the axis of the High Lava Plains as a "soft" edge to the zone of oblique extension that lies mainly to the south. This transitional boundary is essentially aseismic and is characterized along its entire length, especially in the Snake River Plain, by Quaternary volcanic fields***.

The plain's origin remains uncertain. It is not known what rocks and structures are present at depths of more than a few thousand feet. However, recent geophysical and tectonic modeling studies have provided much insight about the deep crustal structure of the Snake River Plain. Continuing collection and analysis of geological and geophysical data, coupled with theoretical modeling efforts, may someday provide a more definitive answer.

\section{STRUCTURE}

High-angle normal faults that bound the western plain (pl. 1) have long been recognized (Russell, 1902). Gravity, seismic, and geologic studies suggest at least $9,000 \mathrm{ft}$ of aggregate vertical displacement (Malde, 1959, p. 272). Most faults are downthrown toward the axis of the plain, resulting in the grabenlike structure of the western plain. Interpretation of seismic data by Wood and Anderson (1981, p. 14) suggests deep-seated faulting in the central part of the western plain, as well as along its margin (fig. 3). Faults are not well defined along the boundary of the eastern plain. However, on the basis of seismic data and modeling, Sparlin and others (1982, p. 2619-2633) suggested that faults along the northern boundary of the eastern plain may have an aggregate throw of 
as much as $13,000 \mathrm{ft}$. Seismic data also indicate that volcanic rock fill in the eastern plain is as much as $16,000 \mathrm{ft}$ thick. Major faults have not been defined along the southern boundary of the eastern plain, but geophysical data indicate faults about $25 \mathrm{mi}$ north of the boundary. These faults may delimit the northern extent of adjacent preCretaceous sedimentary rocks that extend at shallow depth into the plain. Surface evidence of faulting commonly is masked by overlying young basalt and unconsolidated sedimentary rocks. Sparlin and others (1982) concluded that a deepseated intrusive body may be present in the upper crust underlying the asymmetric grabenlike eastern Snake River Plain. Miocene volcanic rocks exposed at the eastern plain's margin and underlying the Quaternary basalt near the margin were highly faulted and severely eroded prior to the plain's formation (Malde and Powers, 1962, p. 1201).

Rift zones (pl. 1) in the eastern plain, most of which are normal to the plain's axis, appear to be extensions of adjacent basin-and-range structures (Kuntz, 1978, p. 9). Volcanic vents in the eastern plain appear to be randomly scattered, but some are aligned along rift zones.

\section{STRATIGRAPHY}

A generalized stratigraphic column for the Snake River basin (pl. 1) was compiled from published reports and maps. Major rock units in the Snake River basin are described on plate 1 . Some of the described units are a composite of those shown on detailed geologic maps. Combining was possible because of geologic and hydrologic similarities. Detailed stratigraphic information is available for only a few drill holes on the Snake River Plain. The deepest drill hole, about $8 \mathrm{mi}$ northwest of Boise (fig. 3), bottomed at $14,007 \mathrm{ft}$ in silicic volcanic rocks of probable middle Miocene age (Wood and Anderson, 1981, p. 12).

Miocene rocks are an assortment of basalt flows, rhyolitic ash flows, welded tuff, clay, silt, sand, and gravel that interfinger complexly, with many facies changes. Near the western margin of the plain, the Miocene Columbia River Basalt Group overlies older alluvium (probably the Miocene Payette Formation) and silicic volcanic rocks of an unnamed group. The presence of outcrops of Cretaceous granite (the Idaho batholith) on both sides of the western plain indicates that granite may be the basement rock.

Steeply dipping pre-Cretaceous rocks, whose strike is normal to the axis of the eastern plain,

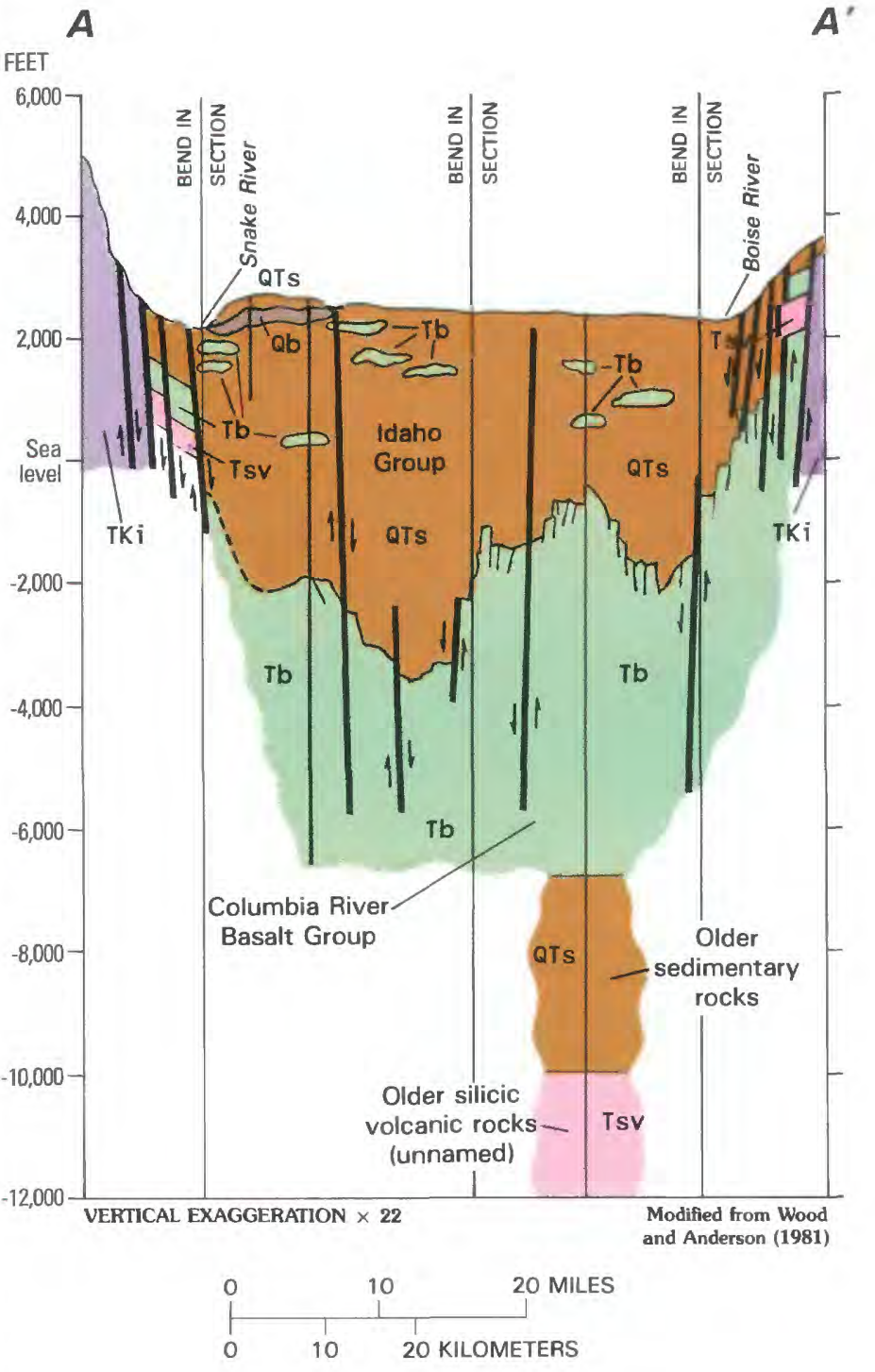

\section{EXPLANATION}

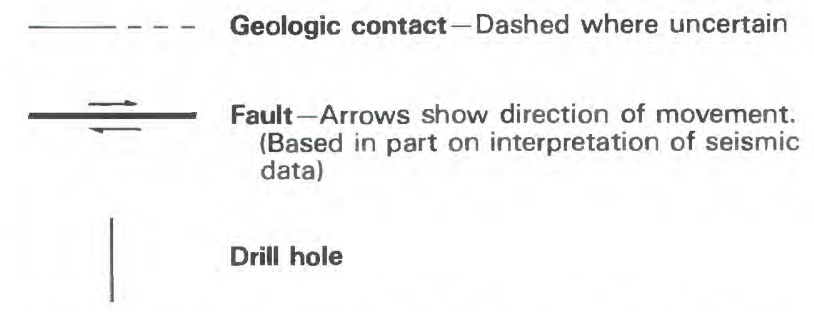

FIGURE 3.-Geologic cross section $A-A$ ', western Snake River Plain. $\mathrm{Qb}$, younger basalt; QTs, older sedimentary rocks; Tb, older basalt; Tsv, older silicic volcanic rocks; TKi, intrusive rocks. See plate 1 for description of map units and location of section. Owing to scale, some thin surficial deposits shown on plate 1 are not shown on cross section. 
end abruptly at the plain's northern margin. Along much of the southern margin, windblown deposits overlie and mask the pre-Cretaceous rocks. PreCretaceous sedimentary and metamorphic rocks may underlie the eastern plain at depth, but their presence has not been proved. A 10,365-ft drill hole east of Arco bottomed in welded tuff and silicic volcanic flow rock, which Doherty and others (1979, p. 1) described as inner caldera fill. The silicic volcanic rocks probably are correlative with the Idavada Volcanics of Miocene age, which, with the Miocene and Pliocene Salt Lake Formation, commonly underlie Miocene basalt in the eastern plain. For convenience, the Miocene basalt herein will be referred to as Banbury Basalt, a basal formation of the Idaho Group. Malde and Powers (1962, 1972) and Malde (1982) studied stratigraphic relations in the western Snake River Plain and correlated Cenozoic rock units. They made a detailed subdivision of the Miocene to Pleistocene Idaho Group and the Pleistocene and Holocene Snake River Group.

The Idaho Group consists of, from oldest to youngest, the Poison Creek Formation, Banbury Basalt, Chalk Hills Formation, Glenns Ferry Formation, Tuana Gravel, Bruneau Formation, and Black Mesa Gravel (Malde and Powers, 1962, p. 1203). The Miocene and Pliocene Salt Lake Formation, Miocene Starlight Formation, and Pliocene and Pleistocene Yellowstone Group in the eastern plain are, in general, stratigraphically equivalent to the Idaho Group.

The Bruneau Formation crops out in the Snake River Plain west of Bliss. Malde and Powers (1962, p. 1210) mapped a sedimentary member of the Bruneau Formation east of Bliss to Hagerman (pl. 1). On the basis of age dating and extensive field observations, Malde (1982) revised the chiefly lacustrine sedimentary deposits of the Bruneau Formation east of Bliss, named the unit the Yahoo Clay of late Pleistocene age, and assigned it to the upper part of the Snake River Group. The Yahoo Clay overlies the McKinney Basalt and underlies the Crowsnest Gravel, which Malde (1982, p. 627) assigned to a younger stratigraphic position from his previous usage.

Overlying the Idaho Group in much of the plain are rocks of the Snake River Group. Formations in the Snake River Group, from oldest to youngest, are Madson Basalt, Thousand Springs Basalt, Sand Springs Basalt, Wendell Grade Basalt, McKinney Basalt, Yahoo Clay, Crowsnest Gravel, and Melon Gravel (Malde, 1982, p. 618). Most formations are exposed in and north of the Snake River canyon near the dividing line between eastern and western parts of the plain. In the eastern plain near Pocatello, the Big Hole Basalt unit is part of the Snake River Group. The American Falls Lake Beds, Michaud Gravel, Raft Formation, and Sunbeam Formation, all of Pleistocene age, are stratigraphically equivalent to similar units of the Idaho Group.

A 90-mi reach of the north Snake River canyon wall from King Hill to Milner (fig. 1) was mapped as part of this study (pl. 2). Mapping helped to define stratigraphic relations, as well as to locate and determine geologic controls on springs (H.R. Covington, U.S. Geological Survey, written commun., 1984). The canyon is as much as $700 \mathrm{ft}$ deep in places along this reach. Stratigraphic relations observed in the canyon appear to extend into the subsurface on the basis of correlation with deep drill holes north of the canyon.

The oldest rocks that crop out in the Snake River canyon just west of Twin Falls are Banbury Basalt and sedimentary rocks of the Idaho Group. East of Twin Falls, rhyolite lava flows (Idavada Volcanics) are exposed for several miles in the bottom of the canyon. In places they are overlain by rocks of the Idaho Group.

Sedimentary rocks and basalt of the Idaho Group are overlain by basalt of the Snake River Group and, in places, by the Yahoo Clay of the Snake River Group. Basalt of the Snake River Group is the predominant rimrock on the north side of the canyon from King Hill to Milner. On the south side of the canyon, the surficial rock is basalt of the Idaho Group. As part of the RASA study, a $1,123-\mathrm{ft}$ test hole was drilled about $10 \mathrm{mi}$ northeast of the Snake River canyon (figs. 1, 4). The stratigraphic sequence penetrated in the test hole is similar to that in the canyon (Whitehead and Lindholm, 1984, p. 17).

Holocene eolian deposits, less than $1 \mathrm{ft}$ to several hundred feet thick, mantle basalt and sedimentary rocks in parts of the plain. Holocene alluvium overlies basalt and older alluvial sedimentary deposits in channels and flood plains of perennial streams.

\section{AREAL DISTRIBUTION AND DESCRIPTION OF ROCKS}

Quaternary basalt of the Snake River Group is the predominant rock in the Snake River Plain. Sedimentary rocks, intercalated with the basalt, are present along the margins of the eastern plain and are widespread in the western part. Several rock types that crop out in only a few places on the plain 
are more abundant in the subsurface and in areas adjacent to the plain.

\section{OLDER SILICIC VOLCANIC ROCKS}

Tertiary silicic volcanic rocks (Idavada Volcanics, unit Tsv, pl. 1) are common in the Snake River drainage basin and are exposed on the Snake River

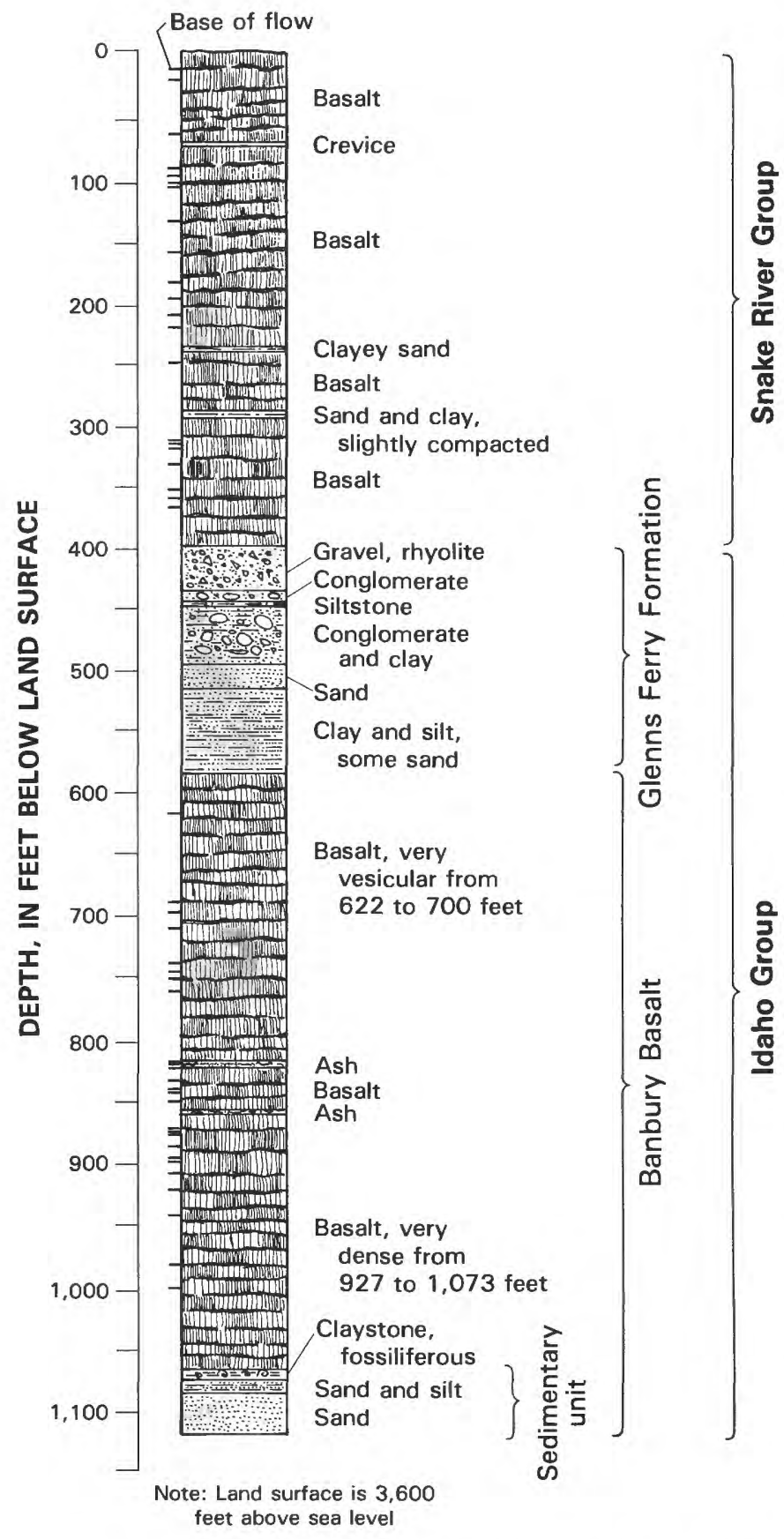

FIGURE 4.-Lithologic log of RASA test hole 7S-15E-12CBA1.
Plain in a few places. However, owing to the map scale, some small outcrops are not shown on plate 1 . The Idavada Volcanics predominates in the older silicic volcanic rock unit. Although outcrops are rare, the Idavada Volcanics is present in the Snake River canyon near Twin Falls and at depth along the plain's margin, as shown on most of the geologic cross sections and geologic profiles (pls. 2,3).

Embree and others (1982, p. 335-336) proposed that much of the basalt of the Snake River Group is underlain by silicic volcanic rocks associated with buried calderas. Big Southern and East Buttes (pl. 1; fig. 1) southeast of Arco may be rim remnants of a buried caldera. Embree and others (1982) correlated rhyolitic ash flows around the margin of the eastern plain with specific buried calderas in and near the plain. Silicic volcanic rocks are progressively younger from west to east.

The Starlight Formation, near the southeastern margin of the plain, is predominantly a bedded rhyolitic tuff with sedimentary interbeds and some basaltic breccia (Trimble, 1976, p. 36) and is younger than the Idavada Volcanics.

Primary porosity of the Idavada Volcanics and related rocks is low; however, faults provide moderate to high secondary porosity. Porosity in lava tubes, cinders, and unconsolidated ash flows is moderate to high.

\section{OLDER BASALT}

The older basalt unit (unit Tb, pl. 1) includes flood-type basalt equivalent in age to the Columbia River Basalt Group and the Banbury Basalt of the Idaho Group. The Columbia River Basalt Group crops out near the Idaho-Oregon State line, in Oregon, and north of the plain between Boise and Weiser. The Columbia River Basalt Group is below sea level in most of the western plain and underlies chiefly Tertiary and Quaternary sedimentary rocks. In the rest of the plain, the older basalt unit is the Banbury Basalt of the Idaho Group or its equivalent and is commonly well above sea level, as shown in geologic cross sections $B-B^{\prime}$ through $J_{-} J^{\prime}$ (pl. 3).

Depth to basalt varies greatly in the plain (pl.4). Where depth to the first volcanic unit is more than $100 \mathrm{ft}$, Tertiary basalt is commonly present; at lesser depths, Quaternary basalt is generally present. Where there is no basalt, silicic volcanic rocks underlie sedimentary rocks. Geologic cross sections $F-F^{\prime}$, $H-H^{\prime}$, and $I-I^{\prime}$ show that Quaternary basalt is as much as $5,000 \mathrm{ft}$ thick in the central part of the eastern plain. Where thickest, the lower parts of the sequence may be basalt in the upper part of the 
Idaho Group (QTb) or Banbury Basalt in the lower part of the Idaho Group (Tb). Flow rocks of the Idavada Volcanics (Tsv) also may be present but are difficult to differentiate in the subsurface, owing to absence of drill-hole data.

Thin (less than $50 \mathrm{ft}$ thick), shallow (less than $50 \mathrm{ft}$ deep) Quaternary basalt flows of small areal extent were not considered in mapping the depth to the first volcanic unit. These flows are typically stringers of basalt deposited in shallow buried stream channels, largely in the western plain.

The Tertiary Banbury Basalt west of Twin Falls was divided into three parts (Malde and Powers, 1962, p. 1204). The lower part consists of at least $400 \mathrm{ft}$ of greatly altered olivine basalt. The middle part is a sedimentary interflow, about $100 \mathrm{ft}$ thick, consisting of brown sand and pebble gravel in lenticular stream deposits and clay and silt in lake deposits. The upper part is similar to the lower but is less altered. In the RASA test hole (fig. 4), Banbury Basalt flows average $48 \mathrm{ft}$ in thickness. The highly vesicular character of the uppermost $122 \mathrm{ft}$ suggests proximity to a vent from which lava was extruded. The remainder of the Banbury Basalt is dense. The few vesicles and fractures in the dense basalt are filled with clay minerals that greatly reduce porosity. The sedimentary unit at the bottom of the test hole is assumed to be the middle member of the Banbury Basalt.

Visual inspection of core samples from the RASA test hole shows that porosity of the Banbury Basalt is low compared with that of the overlying Quaternary basalt (table 1). Basalt of the Snake River Group typically is more fractured and generally lacks secondary mineralization.

Basalt from the test hole was chemically analyzed and compared with basalt from other areas on the plain (table 2). Chemical differences between Banbury Basalt and basalt of the Snake River Group are minor. Samples of Banbury Basalt from the RASA test hole from 619.7 to $1,067.5 \mathrm{ft}$ are described in table 3 .

\section{OLDER ALLUVIUM}

Older alluvium (unit QTs, pl. 1) is widespread in the western plain. Included in the older alluvium unit are sedimentary rocks of the Idaho Group, the Payette and Salt Lake Formations, and terrace gravels. Total thickness of unconsolidated sedimentary rocks was determined from a few deep drill holes and was estimated elsewhere from geophysical data (pl. 5). Thickness ranges from a featheredge around basalt outcrops to as much as $5,000 \mathrm{ft}$ near the Idaho-Oregon State line.
TABLE 1.-Summary of vesicularity in test hole 7S-15E-12CBA1

[Modified from Whitehead and Lindholm, 1984]

\begin{tabular}{|c|c|c|}
\hline $\begin{array}{c}\text { Vesicularity } \\
\text { (classification of Nace } \\
\text { and others, 1975) }\end{array}$ & $\begin{array}{c}\text { Basalt of Snake River } \\
\text { Group ( } 1 \mathrm{ft} \text { below land } \\
\text { surface to } 403 \mathrm{ft} \text { ), as } \\
\text { percentage of total } \\
\text { interval }\end{array}$ & $\begin{array}{l}\text { Banbury Basalt of } \\
\text { Idaho Group } \\
\text { (590 to } 1,073 \mathrm{ft}), \\
\text { as percentage of } \\
\text { total interval }\end{array}$ \\
\hline $\begin{array}{l}\text { Very vesicular } \\
\text { (more than } 25 \text { percent } \\
\text { voids by volume) }\end{array}$ & 4 & ${ }^{1} 17$ \\
\hline $\begin{array}{l}\text { Vesicular } \\
\text { (10-25 percent voids) }\end{array}$ & 31 & 11 \\
\hline $\begin{array}{l}\text { Slightly vesicular } \\
\text { (1-10 percent voids) }\end{array}$ & 22 & 18 \\
\hline $\begin{array}{l}\text { Minutely vesicular } \\
\text { (ordinarily less than } \\
5 \text { percent voids; diameter } \\
\text { less than } 0.04 \text { in.) }\end{array}$ & r & 1 \\
\hline $\begin{array}{l}\text { Crystalline } \\
\text { (less than } 2 \text { percent } \\
\text { intercrystalline voids) }\end{array}$ & 28 & ${ }^{2} 53$ \\
\hline
\end{tabular}

170 percent of upper $114 \mathrm{ft}$ is very vesicular; may be part of Idaho Group.
2100 percent of lower $146 \mathrm{ft}$ is crystalline.

The predominance of sedimentary rocks in the western plain is shown on geologic cross sections $B-B^{\prime}$ through $E-E^{\prime}$ (pl. 3). Most of the sedimentary rocks $1,500 \mathrm{ft}$ and more above sea level are in the Idaho Group. The Payette Formation separates flows of the Columbia River Basalt Group in parts of the western plain.

In much of the eastern plain, sedimentary rocks are less than $10 \mathrm{ft}$ thick or, in places, absent. From about longitude $114^{\circ} \mathrm{W}$. eastward along the southern and eastern margins they are thicker. For example, geologic cross section $I-I^{\prime}$ (pl. 3) shows a thick sequence of sedimentary rocks underlying Quaternary basalt near the Snake River. The older alluvium is intercalated with basalt near the margins of the plain, as shown by geologic cross section $H-H$. Cross section $J-J$ through the Mud Lake area shows sedimentary rocks about $200 \mathrm{ft}$ thick near the axis of the plain. These sediments were deposited in lakes where basalt flows from the north and south (pl. 4) formed closed topographic depressions.

In general, the older alluvium consists of lightcolored clay hundreds of feet thick. Along the northern margin of the plain, Pleistocene sand and gravel derived from the bordering mountains extends for several miles onto the plain. Clay interbeds of lacustrine and eolian origin, bedded volcanic ash and tuff, 
TABLE 2.-Comparison of chemical analyses of basalt from test hole 7S-15E-12CBA1 with basalt of the Snake River Group from other areas on the plain

[Modified from Whitehead and Lindholm, 1984]

\begin{tabular}{|c|c|c|c|c|c|c|c|c|c|c|}
\hline \multirow{2}{*}{$\begin{array}{l}\text { Test hole 7S-15E-12CBA1 } \\
\text { (depth, in feet below } \\
\text { land surface) }\end{array}$} & \multicolumn{10}{|c|}{ Chemical analyses, in percent of total 1} \\
\hline & $\mathrm{SiO}_{2}$ & $\mathrm{Al}_{2} \mathrm{O}_{3}$ & $\mathrm{FeO}$ & $\mathrm{MgO}$ & $\mathrm{CaO}$ & $\mathrm{TiO}_{2}$ & $\mathrm{Na}_{2} \mathrm{O}$ & $\mathrm{P}_{2} \mathrm{O}_{5}$ & $\mathrm{~K}_{2} \mathrm{O}$ & $\mathrm{MnO}$ \\
\hline \multicolumn{11}{|l|}{ Banbury (?) Basalt of Idaho Group ${ }^{2}$} \\
\hline $223.2-223.4$ & 46.3 & 13.8 & 14.67 & 6.79 & 9.60 & 3.36 & 2.8 & 0.84 & 0.74 & 0.21 \\
\hline $241.6-241.7$ & 46.3 & 12.3 & 15.30 & 5.88 & 9.62 & 4.13 & 2.5 & 1.08 & .75 & .25 \\
\hline $292.7-298.0$ & 46.3 & 14.8 & 12.87 & 8.63 & 9.98 & 2.53 & 2.5 & .48 & .59 & .20 \\
\hline${ }^{3} 298.5-298.8$ & 43.0 & 11.9 & 11.22 & 6.26 & 16.66 & 2.54 & 2.1 & .51 & .56 & .16 \\
\hline $315.5-315.8$ & 46.8 & 13.6 & 14.09 & 7.10 & 9.93 & 3.20 & 2.7 & .56 & .65 & .21 \\
\hline $322.5-322.7$ & 47.0 & 13.0 & 14.19 & 6.73 & 10.20 & 3.50 & 2.6 & .60 & .66 & .21 \\
\hline $323.8-324.0$ & 47.0 & 13.8 & 13.91 & 7.05 & 9.99 & 3.16 & 2.5 & .55 & .66 & .21 \\
\hline $355.0-355.2$ & 46.5 & 13.6 & 14.05 & 7.33 & 10.00 & 3.12 & 2.7 & .61 & .64 & .21 \\
\hline $363.6-363.8$ & 46.9 & 14.1 & 13.74 & 6.95 & 10.08 & 3.08 & 2.8 & .60 & .60 & .20 \\
\hline $403.4-403.5$ & 47.2 & 13.8 & 14.04 & 7.12 & 10.08 & 3.13 & 2.7 & .61 & .61 & .21 \\
\hline 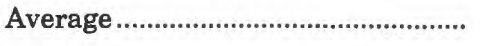 & 46.3 & 13.5 & 13.81 & 6.98 & 10.61 & 3.10 & 2.6 & 0.64 & 0.65 & 0.21 \\
\hline $619.7-620.0$ & 47.4 & 14.3 & 12.67 & 7.75 & 10.64 & 2.51 & 2.9 & 0.37 & 0.50 & 0.20 \\
\hline $627.4-627.6$ & 47.0 & 14.3 & 13.00 & 7.30 & 10.73 & 2.64 & 2.3 & .39 & .36 & .20 \\
\hline $1,067.2-1,067.5$ & 46.7 & 14.7 & 12.06 & 7.15 & 10.64 & 2.66 & 2.7 & .47 & .37 & .18 \\
\hline 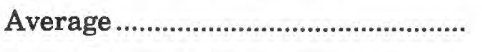 & 47.0 & 14.4 & 12.58 & 7.40 & 10.67 & 2.60 & 2.6 & 0.41 & 0.41 & 0.19 \\
\hline \multicolumn{11}{|l|}{ Basalt of Snake River Group } \\
\hline $\begin{array}{l}\text { Average of } 17 \text { analyses from } \\
\text { central part of the plain }\end{array}$ & 46.4 & 15.1 & 12.10 & 6.83 & 9.64 & 3.07 & 2.7 & 0.86 & 0.65 & 0.20 \\
\hline $\begin{array}{l}\text { Average of } 38 \text { analyses from } \\
\text { other locations on the plain }{ }^{5} \ldots . . .\end{array}$ & 46.8 & 14.8 & 10.29 & 7.59 & 9.87 & 2.97 & 2.4 & 0.68 & 0.62 & 0.17 \\
\hline
\end{tabular}

${ }^{1}$ Percent of total analyses ranges from 94.91 to 99.50 .

${ }^{2}$ Chemical analyses by X-ray fluorescence method. Analysts, P.P. Hearn and B.A. Scott (U.S. Geological Survey, written commun., 1983).

3 Anomalous values may be due to analytical error.

${ }^{4}$ Kuntz and Dalrymple (1979, p. 19-20). Chemical analyses by X-ray fluorescence method.

${ }^{5}$ H.A. Powers (U.S. Geological Survey, written commun., 1963). Analytical methods unknown.

and basalt flows also are included in the older alluvium. Sedimentary rocks are coarsest in the upper 200 $\mathrm{ft}$. In the RASA test hole (fig. 4), $200 \mathrm{ft}$ of the Glenns Ferry Formation separates the Banbury Basalt from basalt of the Snake River Group. Similar stratigraphic relations elsewhere in the eastern plain, chiefly near the margins, were noted on drillers' logs.

\section{YOUNGER SILICIC VOLCANIC ROCKS}

Ash-flow tuff of the upper part of the Yellowstone Group and the Plateau Rhyolite (unit Osv, pl. 1) is present in the extreme northeastern part of the Snake River Plain (geologic cross section $F-F^{n}$, pl. 3) and may underlie Quaternary basalt elsewhere in the eastern plain. The tuff, which is similar to rocks of the Idavada Volcanics, is related to Quaternary volcanism on the Yellowstone Plateau. Where frac- tured, the tuff has high porosity. Thick, nonwelded ash beds with sandy texture are also present.

\section{YOUNGER BASALT}

Quaternary olivine tholeiitic basalt (Leeman, 1982 , p. 162) of the Snake River Group (unit Qb, pl. 1) is the most extensive rock unit in the eastern plain. In large parts of the western plain, basalt is absent, and unconsolidated sedimentary rocks are its stratigraphic equivalent. Owing to chemical and mineralogic similarities, the Quaternary and Tertiary basalt in the upper part of the Idaho Group (unit $\mathrm{QTb}$, pl. 1) is discussed with basalt of the Snake River Group. It is not always possible to distinguish between the two basalts, as indicated by the arbitrary contacts between the two map units on geologic cross sections $F-F^{\prime \prime}, H-H$, and $I-I$ (pl. 3). The older 
TABLE 3.-Mineralogic analyses of selected samples of basalt from test hole 7S-15E-12CBA1

[Analyses by scanning electron microscope-energy dispersive X-ray fluorescence techniques. Analysts: W.W. Wood and P.P. Hearn (U.S. Geological Survey, written commun., 1983). Modified from Whitehead and Lindholm (1984)]

\begin{tabular}{lll}
\hline $\begin{array}{c}\text { Depth (feet below } \\
\text { land surface) }\end{array}$ & Description & Modal proportions \\
(percent)
\end{tabular}

$223.2-223.4 \quad$ Vesicular, moderate alteration on vesicle rims, no fillings; olivine phenocrysts, medium to large, some iddingsite alteration, plagioclase phenocrysts, zoned and large, also small to medium unzoned laths; orthopyroxene microphenocrysts; matrix consists of altered opaques plus fibrous alteration products (possibly original ophitic orthopyroxene).

241.6 - $241.7 \quad$ Highly vesicular, vesicles show fillings of both detrital material (possibly volcanic ash) and isotropic crystalline material (possibly clay-halloysite), vesicle rims show minimal oxide alteration; plagioclase phenocrysts, medium, unzoned laths; orthopyroxene phenocrysts (hypersthene), medium, subhedral; matrix consists of small anhedral orthopyroxene and opaques and small to medium unzoned plagioclase laths; opaques mostly primary igneous phase.

298.5 - $298.8 \quad$ Vesicular, vesicle rims show iron oxide alteration, vesicles filled with fine-grained material (possibly volcanic ash), of quartz, plagioclase calcite, clays, and opaques; fillings altered (clay?, prehnite?, calcite?), possibly minor hydrothermal alteration after deposition; olivine microphenocrysts, subhedral; plagioclase laths, unzoned; orthopyroxene microphenocrysts, subhedral; matrix is devitrified glass, fibrous-brown alteration products (iron oxide and chlorite-serpentinite).

$315.5-\quad 315.8 \quad$ Highly vesicular, vesicle rims strongly altered to iron oxides, severalvesicles lined with isotropic semicrystalline substance (possibly halloysite); olivine microphenocrysts; plagioclase microphenocrysts, medium laths, unzoned, pilotaxitic texture in some; orthopyroxene microphenocrysts; matrix is highly altered, opaque iron oxide and fibrous-brown chloriteserpentinite; this material probably was ophitic orthopyroxene in primary basalt.

322.5 - $\quad 322.7 \quad$ Vesicular, vesicle rims show minor alteration, no visible vesicle fillings,other vesicle rims strongly altered with iron oxide; plagioclase microphenocryst laths, unzoned; orthopyroxene microphenocrysts, small to medium grains (brownish-green hypersthene); matrix consists of altered ophitic orthopyroxene (fibrous chloriteserpentinite) and iron oxide secondary alteration.

323.8 - $\quad 324.0 \quad$ Vesicular, vesicle rims slightlỳ altered, no void fillings; olivine microphenocrysts (altered to iron oxide and iddingsite); plagioclase microphenocrysts (altered slightly to iron oxide) anhedral, few are euhedral; orthopyroxene microphenocrysts (altered slightly to iron oxide), slightly pleochroic brown-yellow-green.

355.0 - $355.2 \quad$ Vesicular, vesicle rims altered to iron oxide, some vesicles filled with fragmental detrital material or ash; olivine microphenocrysts, iddingsite alteration; plagioclase microphenocrysts, altered; opaque matrix iron oxide secondary alteration, includes very small orthopyroxene aggregates.
Olivine 17

Plagioclase 38

Orthopyroxene microphenocrysts

Orthopyroxene, ophitic, altered

Opaques

Voids, unfilled

Plagioclase phenocrysts

Orthopyroxene phenocrysts

Plagioclase matrix

Orthopyroxene matrix

Opaques

Voids

Void filling, isotropic

2

26

9

Olivine

Plagioclase

Orthopyroxene

Opaques

Voids, includes fillings

Olivine microphenocrysts 1

Plagioclase microphenocrysts

Orthopyroxene microphenocrysts

Opaque matrix

Voids, includes fillings

Plagioclase microphenocrysts

Olivine microphenocrysts

Plagioclase microphenocrysts

Orthopyroxene microphenocrysts

Opaque matrix

21

Voids

Olivine microphenocrysts

Voids, includes fillings 
TABLE 3.-Mineralogic analyses of selected samples of basalt from test hole 7S-15E-12CBA1-Continued

[Analyses by scanning electron microscope-energy dispersive X-ray fluorescence techniques. Analysts: W.W. Wood and P.P. Hearn (U.S. Geological Survey, written commun., 1983). Modified from Whitehead and Lindholm (1984)]

\begin{tabular}{|c|c|c|c|}
\hline $\begin{array}{l}\text { Depth (feet below } \\
\text { land surface) }\end{array}$ & Description & $\begin{array}{l}\text { Modal proportions } \\
\text { (percent) }\end{array}$ & \\
\hline $363.6-363.8$ & $\begin{array}{l}\text { Vesicular, vesicle rims altered to iron oxide, no fillings; } \\
\text { olivine microphenocrysts, some alteration to iddingsite; } \\
\text { plagioclase microphenocrysts, unzoned, euhedral to } \\
\text { subhedral, some pilotaxitic areas; orthopyroxene micro- } \\
\text { phenocrysts; matrix shows alteration to iron oxide and } \\
\text { fibrous chlorite-serpentinite (possibly from original } \\
\text { ophitic orthopyroxene). }\end{array}$ & $\begin{array}{l}\text { Olivine microphenocrysts } \\
\text { Plagioclase microphenocrysts } \\
\text { Orthopyroxene microphenocrysts } \\
\text { Opaque matrix, includes alteration } \\
\text { products } \\
\text { Voids }\end{array}$ & $\begin{array}{r}11 \\
39 \\
1 \\
27 \\
22\end{array}$ \\
\hline $403.4-403.5$ & $\begin{array}{l}\text { At contact with sedimentary rocks; plagioclase, euhedral } \\
\text { to subhedral laths; orthopyroxene, ophitic (some alter- } \\
\text { ation, deuteric); orthopyroxene microphenocrysts; } \\
\text { isotropic phenocrysts, clear, high relief, few opaques. }\end{array}$ & $\begin{array}{l}\text { Plagioclase microphenocrysts } \\
\text { Orthopyroxene, ophitic } \\
\text { Orthopyroxene microphenocrysts } \\
\text { Isotropic phenocrysts } \\
\text { Opaques }\end{array}$ & $\begin{array}{r}30 \\
55 \\
7 \\
6 \\
2\end{array}$ \\
\hline $619.7-620.0$ & $\begin{array}{l}\text { Vesicular, vesicles minor, no alteration on rims; } \\
\text { olivine microphenocrysts, partly altered to } \\
\text { iddingsite; plagioclase microphenocrysts, } \\
\text { small to medium, euhedral to subhedral, } \\
\text { show primary volcanic texture; orthopyroxene, } \\
\text { ophitic; opaques show primary crystallization. }\end{array}$ & $\begin{array}{l}\text { Olivine microphenocrysts } \\
\text { Plagioclase microphenocrysts } \\
\text { Orthopyroxene, ophitic } \\
\text { Opaques } \\
\text { Voids }\end{array}$ & $\begin{array}{r}4 \\
44 \\
35 \\
13 \\
4\end{array}$ \\
\hline $627.4-627.6$ & $\begin{array}{l}\text { Vesicular, vesicles filled with detrital material } \\
\text { and isotropic clay; olivine microphenocrysts, } \\
\text { some alteration to iddingsite; plagioclase } \\
\text { microphenocrysts, small euhedral to subhedral } \\
\text { laths; matrix highly altered to iron oxide, } \\
\text { opaques from primary opaques and ophitic } \\
\text { orthopyroxene. }\end{array}$ & $\begin{array}{l}\text { Olivine microphenocrysts } \\
\text { Plagioclase microphenocrysts } \\
\text { Orthopyroxene, ophitic, altered } \\
\text { Opaque matrix } \\
\text { Voids, includes fillings }\end{array}$ & $\begin{array}{r}1 \\
22 \\
5 \\
29 \\
43\end{array}$ \\
\hline $1,067.2-1,067.5$ & $\begin{array}{l}\text { Slightly vesicular, no alteration of the few } \\
\text { vesicle rims, primary igneous texture; olivine } \\
\text { microphenocrysts, some alteration to iddingsite; } \\
\text { plagioclase microphenocrysts; orthopyroxene, } \\
\text { ophitic texture; opaques appear as primary } \\
\text { igneous phases. }\end{array}$ & $\begin{array}{l}\text { Olivine microphenocrysts } \\
\text { Plagioclase microphenocrysts } \\
\text { Orthopyroxene microphenocrysts } \\
\text { Opaques } \\
\text { Voids }\end{array}$ & $\begin{array}{r}4 \\
41 \\
46 \\
9 \\
0\end{array}$ \\
\hline
\end{tabular}

unit has thicker flows that reduce its overall unit porosity. Kuntz and others (1983) recently reclassified some exposures of Idaho Group basalt shown on plate 1 as younger, Snake River Group basalt (unit Qb).

Quaternary basalt is within $10 \mathrm{ft}$ of the land surface in much of the eastern plain (pl. 4). Structure contours of the top of the uppermost volcanic unit show, in a general way, major source areas (vents) for most recent basalt flows. The best example is the pronounced topographic high at Craters of the Moon National Monument, where basalt is less than 2,000 years old. Vents are not shown on plate 4 but are shown on the Idaho State geologic map (Bond and others, 1978).

Several hundred to several thousand feet of Quaternary basalt underlies most of the plain (pl. 3). Basalt is thickest in the central part of the eastern plain (geologic cross sections $F-F^{\prime \prime}, H-H^{\prime}, I-I^{\prime}$, pl. 3) and thins toward the plain's margins. Malde (1965, p. 261) indicated that the basalt may be more than 4,200 $\mathrm{ft}$ thick in troughs between Craters of the Moon National Monument and Idaho Falls. LaFehr and Pakiser (1962, p. D77) suggested that basalt may extend to depths of more than $5,000 \mathrm{ft}$. Basalt thickness is known in only a few deep drill holes and was estimated elsewhere by geophysical methods. As a result, indicated variations in thickness (pl. 3) are approximate and, in some areas, speculative. Included with the mapped basalt are thin sedimentary and silicic volcanic interbeds of small areal extent.

Both pahoehoe and aa flows are present in the Snake River Plain; however, pahoehoe flows seem to predominate. Kuntz and Dalrymple (1979, p. 16) listed three gradational structural units in a typical pahoehoe flow: (1) A top layer less than $6 \mathrm{ft}$ thick of 
fine-grained, vertically and horizontally jointed vesicular basalt; (2) a coarse-grained, massive central layer about 15 to $25 \mathrm{ft}$ thick (may be much less) with intergranular texture and vertical columnar joints and pipes; and (3) a basal layer less than $3 \mathrm{ft}$ thick of finegrained to scoriaceous blocks of oxidized basalt. Basal scoriaceous and oxidized basalt is not present every- where. Zonation in a typical flow of basalt of the Snake River Group is shown in figure 5.

Some ambiguity exists in use of the term "basalt flow." The entire volume of lava extruded during an eruption may be referred to as a flow (flow A through D, fig. 6), or each gush of lava that spread an undefined distance from a vent and formed a

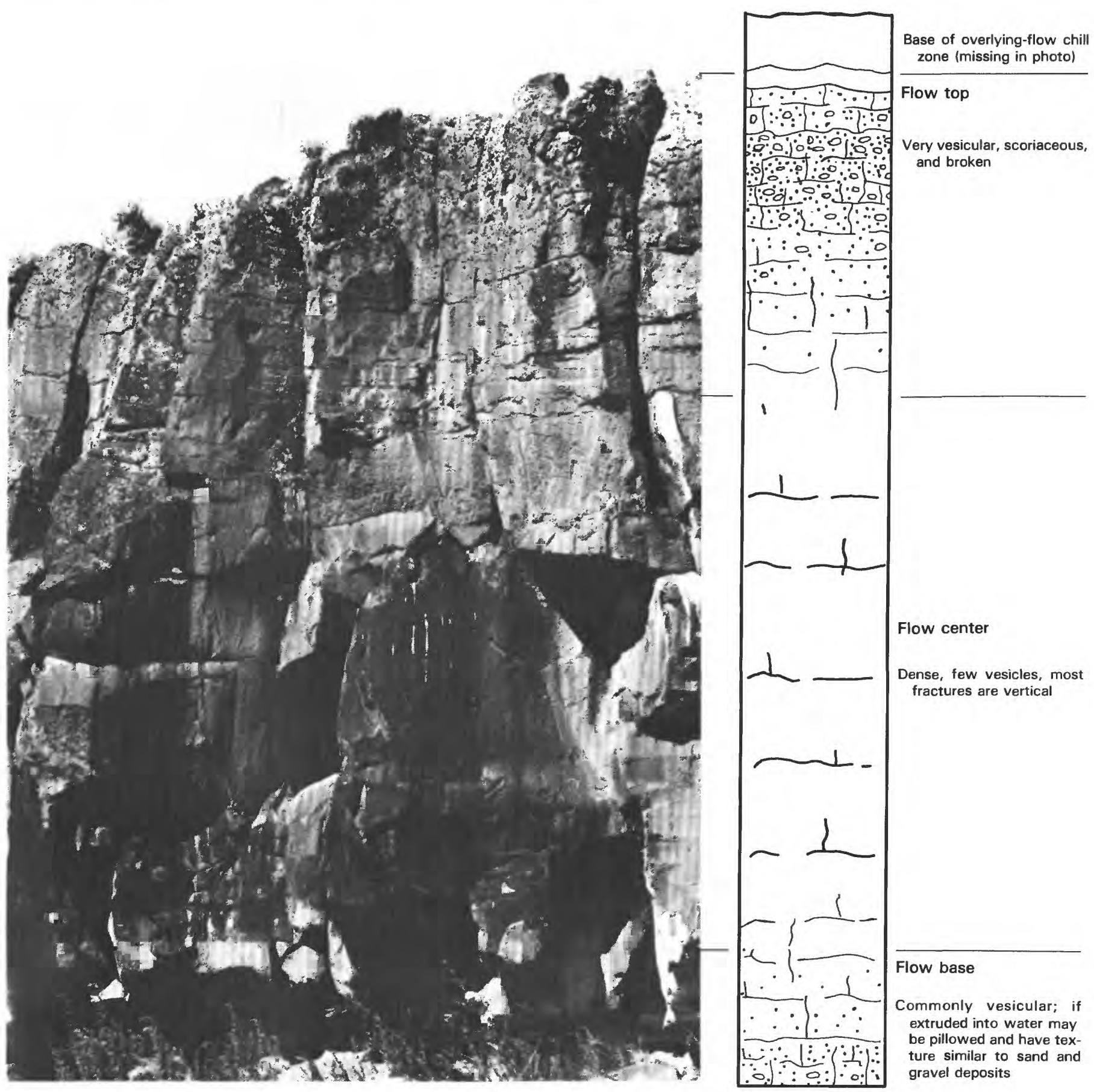

Figure 5.-Zonation in a typical flow of basalt of the Snake River Group. 
crust before subsequent lavas poured over it may be called a flow (numbered units, fig. 6). The terms "flow unit" or "cooled unit" have been suggested by some investigators for the latter type of flow. In this report, each individual distinguishable cooled unit is referred to as a flow.

Basalt surface features (fig. 7) vary widely, owing chiefly to differences in cooling rates. Similar features are present in the subsurface. Lava generally cools rapidly and unevenly, depending on place and rate of extrusion. Rapid cooling and escape of entrapped gases cause vesicles of varying sizes to form. Extremely rapid cooling, as in shallow water, causes steam explosions, and the cooled lava solidifies into a wide size range of generally rounded forms, or pillow lavas. Pillow lavas typically have high porosity, similar to that of sand and gravel. After extrusion, cooling creates a crust on the upper surface of a flow. Continued movement of the underlying lava frac- tures the newly formed outer crust. The fractured crust is incorporated into the moving mass, and rubble zones with many small to large interconnected pore spaces are formed. If lava is intruded between rock units or into fractures, it cools slowly and forms dikes. Overlapping of flows results in interlocked layers of basalt (Nace and others, 1975, p. 15). Flows range in thickness from a few feet to more than 100 $\mathrm{ft}$ and average about 20 to $25 \mathrm{ft}$ (Mundorff and others, 1964, p. 143). Quaternary basalt flows observed in the RASA test hole (fig. 4) average $17 \mathrm{ft}$ in thickness. Individual flows of basalt of the Snake River Group are commonly 50 to $100 \mathrm{mi}^{2}$ in areal extent.

Basalt flows that compose the Snake River Group have similar mineralogic and chemical composition (tables 2 and 3). However, they vary considerably in texture, structure, and thickness. Central parts of many flows and dikes are dense or crystalline and have less than 2 percent megascopic vesicular poros-

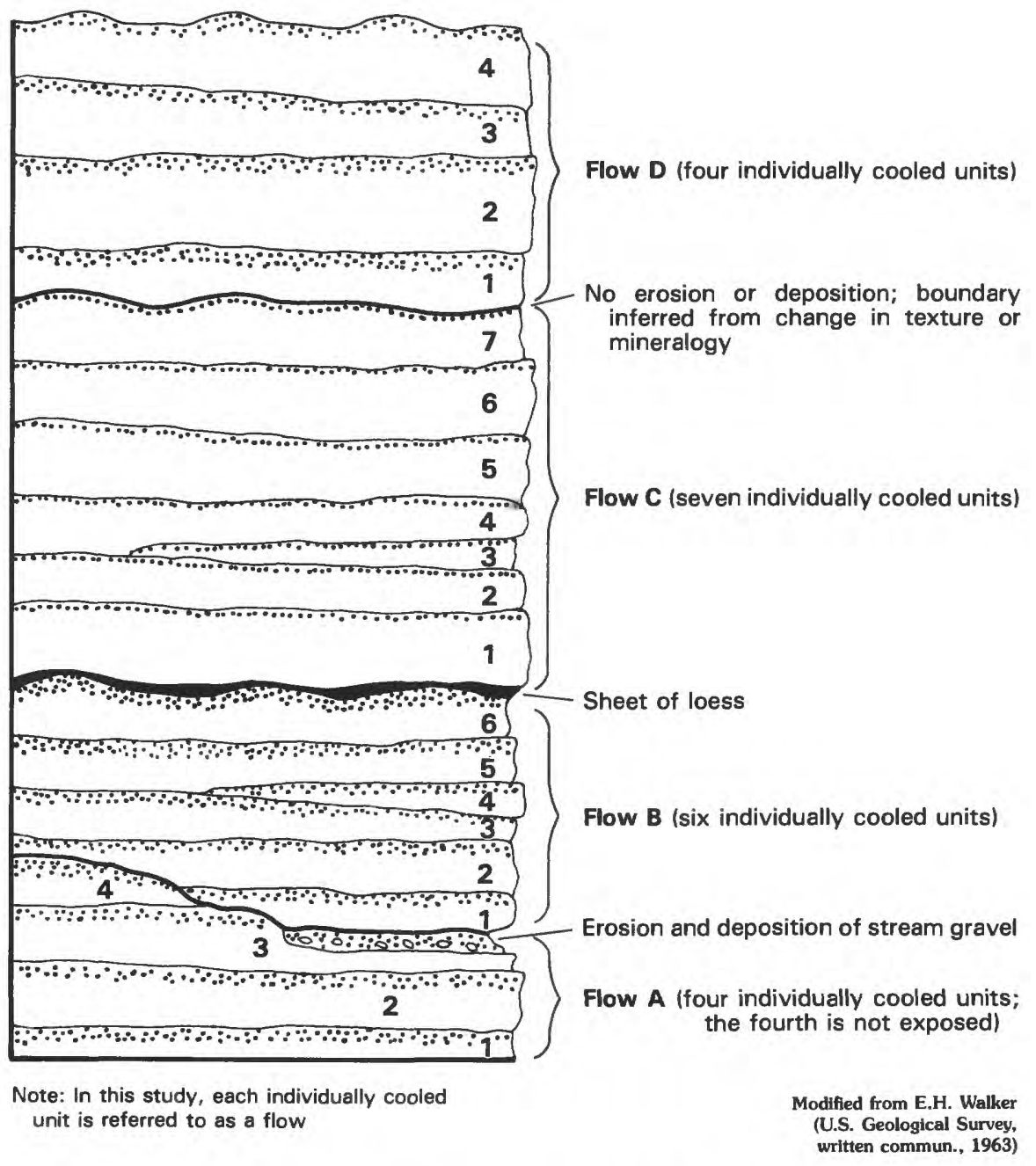

FIGURE 6.-Flow units and cooled units in basalt of the Snake River Group. 
ity. Vesicular porosity near the tops of many flows is as much as 30 percent or more, and many open spaces are interconnected. Vesicular porosity in the RASA test hole is summarized in table 1.

Basalt of the Snake River Group is an olivine tholeiite, some of which contains enough olivine to have a greenish cast. It is typically porphyritic, with phenocrysts of olivine and plagioclase. Some basalt has ophitic to subophitic texture; other basalt is aphanitic. Some volcanic glass is altered to chlorophaeite; iron-bearing minerals may be altered, producing iron oxides. Plagioclase phenocrysts typically are zoned, and most plagioclase crystals are tabular. Some rocks have crys- tals with sieve textures and glomeroporphyritic clots of olivine and plagioclase. Blades of ilmenite and crystals of magnetite are common. Secondary mineralization products are uncommon in the Quaternary basalt, except where calichelike deposits fill vesicles near the land surface (Nace and others, 1975, p. B13).

\section{WINDBLOWN DEPOSITS}

Windblown deposits (unit Qw, pl. 1) mantle basalt and older sedimentary rocks in most of the plain and mask geologic contacts. Where thick enough to plow
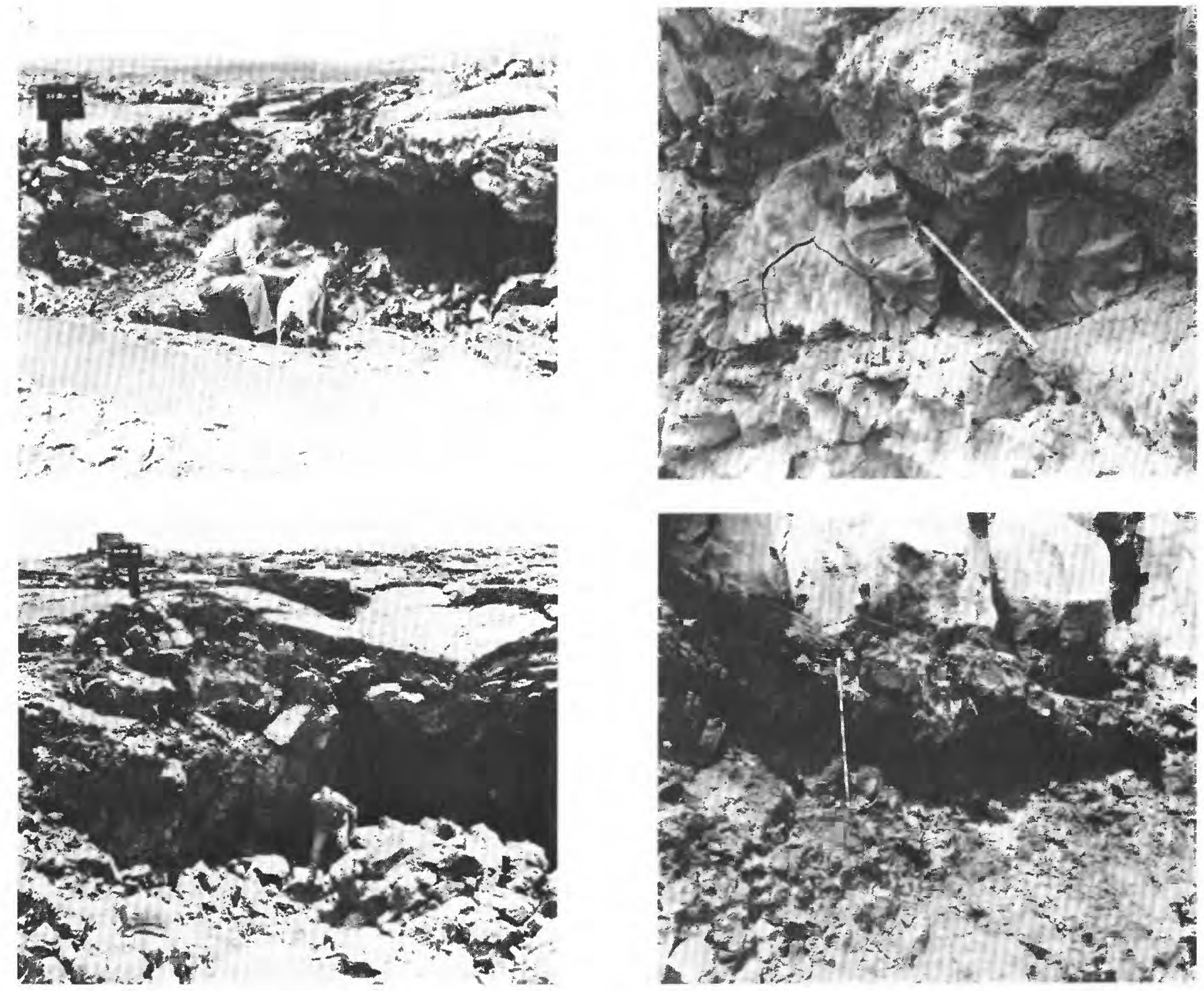

LAVA TUBES

PILLOW LAVA

FiguRe 7.-Surficial features of basalt of the Snake River Group. Ruler is extended to about 36 inches where shown. 

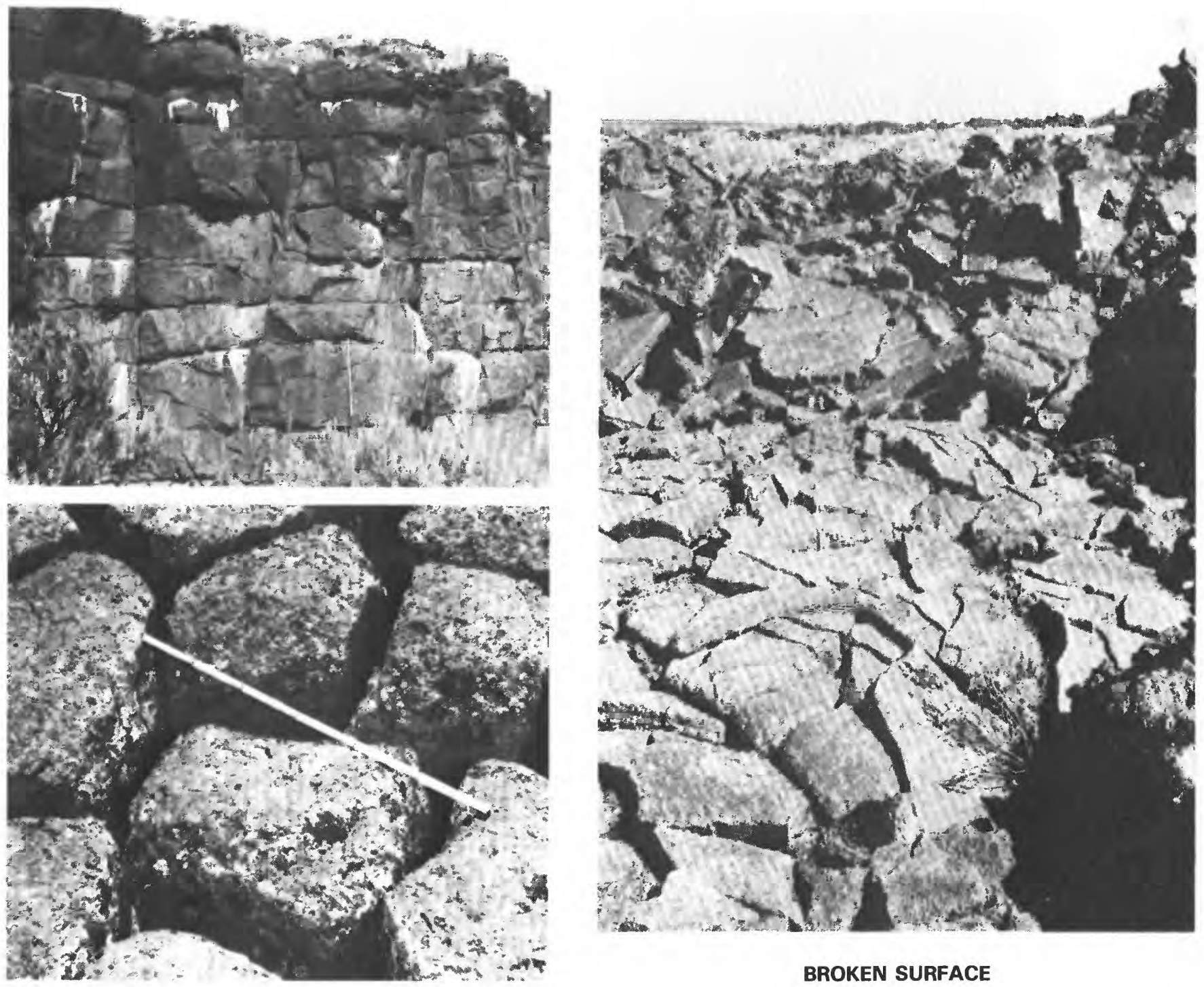

BROKEN SURFACE

COLUMNAR AND POLYGONAL JOINTING

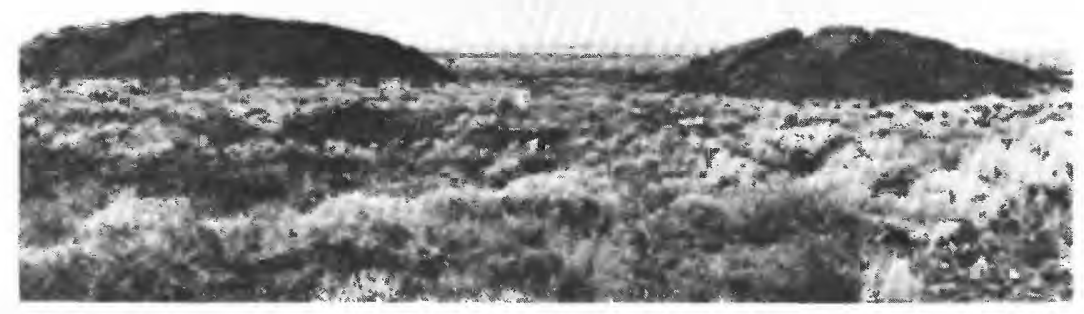

PRESSURE RIDGES

Figure 7.-Continued. 
and of sufficient areal extent, soils formed from eolian deposits are agriculturally productive. About $16 \mathrm{mi}$ south of Mountain Home in the western plain and about the same distance north of Rexburg in the eastern plain, dune sand is several hundred feet thick. Small dunes are widespread in Butte and Jefferson Counties in the eastern plain.

\section{YOUNGER ALLUVIUM}

Quaternary alluvium (unit Qa, pl. 1) is present along most stream channels and commonly consists of sand, gravel, and minor amounts of clay. Floodplain deposits generally have a high porosity. The most notable are alluvial deposits in the Boise River valley. Deposits in narrow channels are not shown on plate 1, owing to the small map scale.

\section{APPLICATION OF SURFACE GEOPHYSICAL METHODS TO SUBSURFACE HYDROGEOLOGIC MAPPING}

Drillers' logs and borehole geophysical logs provided site-specific subsurface hydrogeologic information, but their limited number, spacing, and amount of information did not permit detailed definition of regional subsurface conditions. Therefore, surface geophysical methods were used to supplement information from drill holes.

Previous geophysical studies listed by Whitehead (1986a) provided basic ideas about basin configuration. Many previous studies were designed to define large-scale crustal features; few were concerned about the distribution of rocks in the upper few thousand feet. For this reason, electrical resistivity surveys and gravity modeling were used to help estimate thickness and areal extent of rocks in the plain, with emphasis on defining the limits of Quaternary basalt of the Snake River Group.

\section{ELECTRICAL RESISTIVITY SURVEYS}

The U.S. Geological Survey's Geologic Division completed 221 vertical electrical soundings as part of the RASA study. Soundings made by R.J. Bisdorf (U.S. Geological Survey, written commun., 1982), along with a similar number of soundings made for previous studies (Zohdy and Stanley, 1973; Crosthwaite, 1974; Jackson, 1974; Zohdy and others, 1978; Robinette and Matzner, 1980; Bisdorf, 1983), were used with drill-hole data to map regional variations in the thickness of Quaternary basalt (pl. 3).

One of the assumptions of the electrical resistivity method is that the materials being sounded are isotropic in both horizontal and vertical directions. Basalt is typically anisotropic. As a result, estimates of basalt thickness are generally high, compared with drill-hole data. Zohdy (1974, p. 32) noted the possibility of overestimating basalt thickness.

Electrical resistivity soundings for this RASA study were made using a symmetrical Schlumberger array. Current-electrode spacings ranged from 4,000 to $28,000 \mathrm{ft}$; apparent resistivities ranged from 3.5 to $4,650 \mathrm{ohm}$-meters. Sounding data were computer processed and interpreted by use of a modified version of Zohdy's (1973) inversion program. Computer-generated profiles were created for each of the traverses made during this study and for a traverse from Arco to Blackfoot made during an earlier study. Generalized versions of about $450 \mathrm{mi}$ of computer-generated profiles are shown on plate 6 .

Basalt of the Snake River Group is highly resistive to electrical current. Correlation of resistivity values with major rock types penetrated by deep drill holes indicates that, in general, resistivities of $300 \mathrm{ohm}$-meters and greater in the upper part of the lithologic section indicate Quaternary basalt. Therefore, resistivity profiles were used to help estimate basalt distribution and thickness.

Near the margins of the plain, unsaturated, unconsolidated gravel with resistivities comparable to those of basalt, and saturated, fine-grained sedimentary rocks with reduced resistivities are intercalated with basalt and make interpretation difficult. Near the margins, an apparent resistivity of $100 \mathrm{ohm}-$ meters or greater was interpreted as basalt (profile $\left.S-S^{\prime}\right)$. Drillers' logs were available to aid interpretation in many areas.

High resistivities at depths greater than $3,000 \mathrm{ft}$ may indicate consolidated sedimentary or older volcanic rocks. Where high-resistivity zones are continuous from the surface to depths in excess of the area average, an arbitrary cutoff was made at the average depth to regionalize the interpretation (for example, see the dashed line on the right end of profile $\left.P-P^{\prime}\right)$.

Other exceptions noted using the resistivity method were: (1) The lowest resistivities (less than $7 \mathrm{ohm}$-meters, not shown on the generalized profiles) indicate fine-grained sedimentary rocks, geothermal water, or a combination of the two; (2) zones of faulting associated with geothermal water also may be indicated by low resistivities; and (3) 
the effect of geothermal water may mask lithologic variations (Jackson, 1974), as indicated by the low resistivity of faulted areas flanking the western plain (profile $L-L^{\prime}$ ). In those areas, both sedimentary and volcanic rocks contain geothermal water. Rocks penetrated in the RASA test hole (fig. 4) were in general agreement with lithologic interpretations based on resistivity soundings. Drill holes near other resistivity profiles similarly aided interpretation.

The areal extent of silicic volcanic rocks underlying the plain is mostly unknown. Highly resistive silicic volcanic rocks may be intercalated with or underlie Quaternary basalt in local areas. Silicic volcanic rocks may extend to considerable depths and, if a flow rather than a pyroclastic rock, their electrical resistivity would be similar to that of Quaternary basalt, although porosity would be much lower. In such areas, electrical resistivity cannot be used to distinguish silicic volcanic rocks from basalt.

On most drillers' logs, the Banbury Basalt can be distinguished from basalt of the Snake River Group. Typically, vesicles and fractures in the Banbury Basalt are filled with clay minerals, calcite, and zeolites. Clay filling from serpentinization is also present locally (Malde and Powers, 1972). Secondary fillings tend to reduce the electrical resistivity of the older basalt.

\section{GRAVITY MODELING}

Gravity modeling (fig. 8), based on a regional Bouguer gravity anomaly map of southern Idaho (Berg and Thiruvathuskal, 1967; Mabey and others, 1974), aided in defining the distribution of major rock types and in interpreting gross structural features. Actual modeling extended beyond the plain's boundary, but the results shown in figure 8 are only for that part of the model within the plain's boundary. Models were simplified because the modeling process is highly subjective and does not yield unique solutions.

Gravity values for modeling the western plain were obtained directly from figure 8 . Modeling of the eastern plain required adjustment of the Bouguer anomalies to compensate for the regional effects of a large body of rock, either more areally extensive than the plain or deeply buried (more than $3 \mathrm{mi}$ ) (Mabey, 1978, p. 557). Data from a seismic-refraction study (Sparlin and others, 1982, p. 2619) suggest that a deeply buried body is more likely. These data were used as a basis for the regional residual separation. The separation was made using several methods suggested by Dobrin (1952, p. 86-88).
The modeling program (Talwani and others, 1959) uses two-dimensional polygons of variable sizes, shapes, and assumed density contrasts to represent possible geological bodies inferred from available geologic information. The program required the following assumptions: (1) Polygonal bodies of infinite strike length represent bodies of subsurface density variations, (2) each polygon was of a constant density contrast (compared to an average value for crustal rocks of $2.65 \mathrm{~g} / \mathrm{cm}^{3}$ ), and (3) compaction of material with increasing depth of burial was negligible. The program calculated the polygon's gravitational effects, then summed the effects for plotting against the measured residual gravity anomaly. Polygons were changed, deleted, or added as necessary to comply with known geologic and physical constraints until a best-fit curve was obtained.

\section{AREAL EXTENT AND LITHOLOGY OF THE SNAKE RIVER PLAIN REGIONAL AQUIFER SYSTEM}

The Snake River Plain regional aquifer system as defined in this report extends from Island Park Caldera on the east to Weiser on the west (fig. 1). Most previous ground-water studies of the Snake River Plain have been of the area east of Bliss, which Mundorff and others (1964, p. 142) described as a "series of basalt flows and intercalated pyroclastic and sedimentary materials that underlie the Snake River Plain." Basalt of the Snake River Group east of Bliss is the most transmissive part of the aquifer system. Mundorff and others (1964) did not include the area south of the Snake River from American Falls Reservoir to Salmon Falls Creek as part of the plain. This study included that area as part of the eastern Snake River Plain. The part of the plain from King Hill to Weiser and extending into Oregon is herein referred to as the western Snake River Plain. The division was made at King Hill rather than Bliss because long-term discharge data are available for the Snake River gaging station at King Hill. Although for purposes of this study it was feasible to divide the plain into eastern and western parts, together they compose the larger Snake River Plain regional aquifer system.

\section{WESTERN PLAIN}

Aquifers in the western Snake River Plain consist of unconsolidated to weakly consolidated sedimentary rocks with minor amounts of basalt; however, basalt is a major aquifer in the vicinity of Mountain 


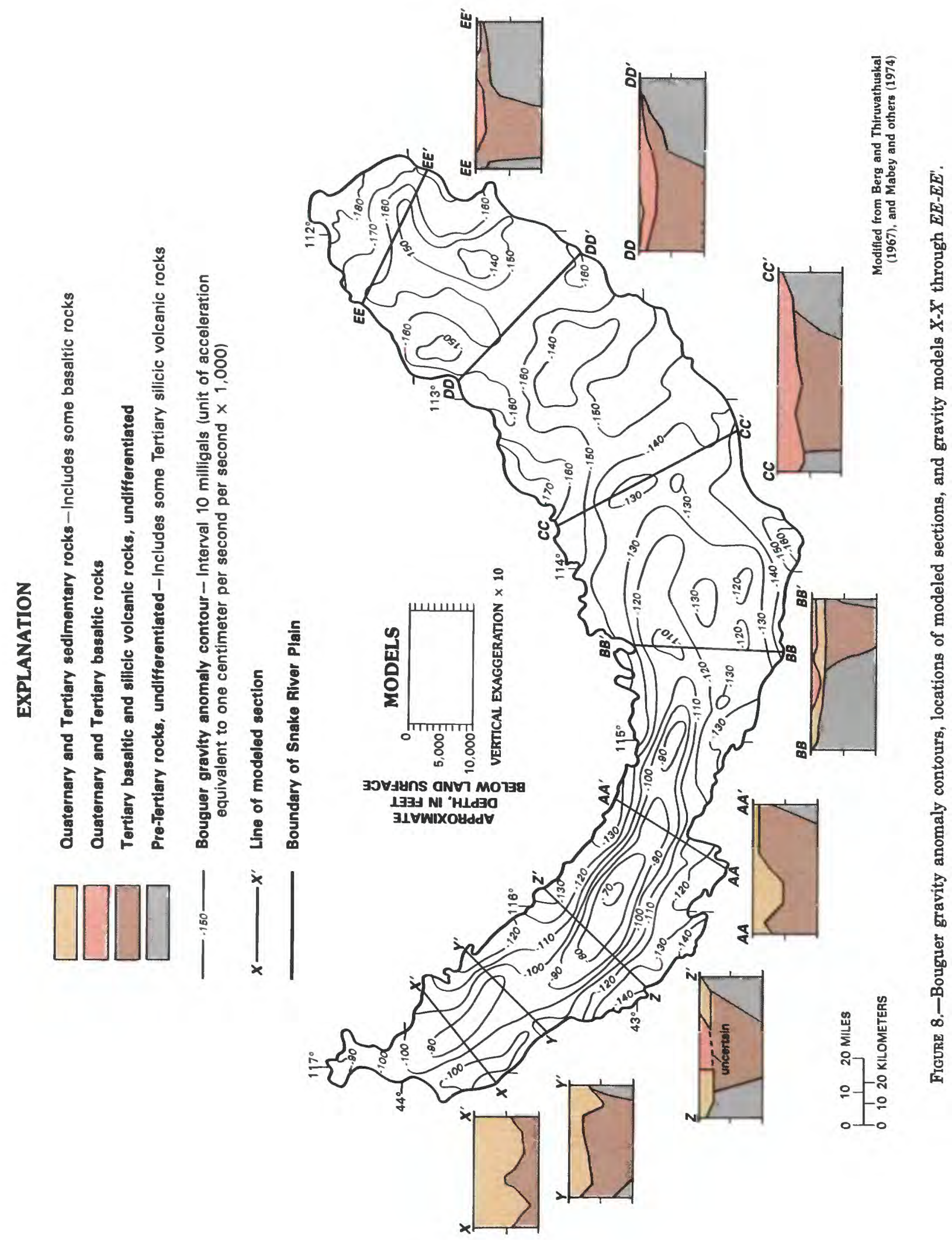


Home (pl. 1). Upper Pleistocene and Holocene sand and gravel aquifers predominate along the Boise River and the northern boundary of the plain. The particle size of the sediment generally decreases toward the southwest with increasing distance from its source, as shown in figure 9. Older Quaternary and fine-grained Tertiary sedimentary rocks (Pleistocene and Pliocene) of the Idaho Group predominate in the remainder of the western plain. In many areas, they yield only small quantities of water.

Discontinuous lenses of gravel and sand within the fine-grained sedimentary rocks (fig. 10) yield small to moderate quantities of water to wells. In places, permeable zones are as much as $5,500 \mathrm{ft}$ below land surface (Anderson and Wood, 1981, p. 38).

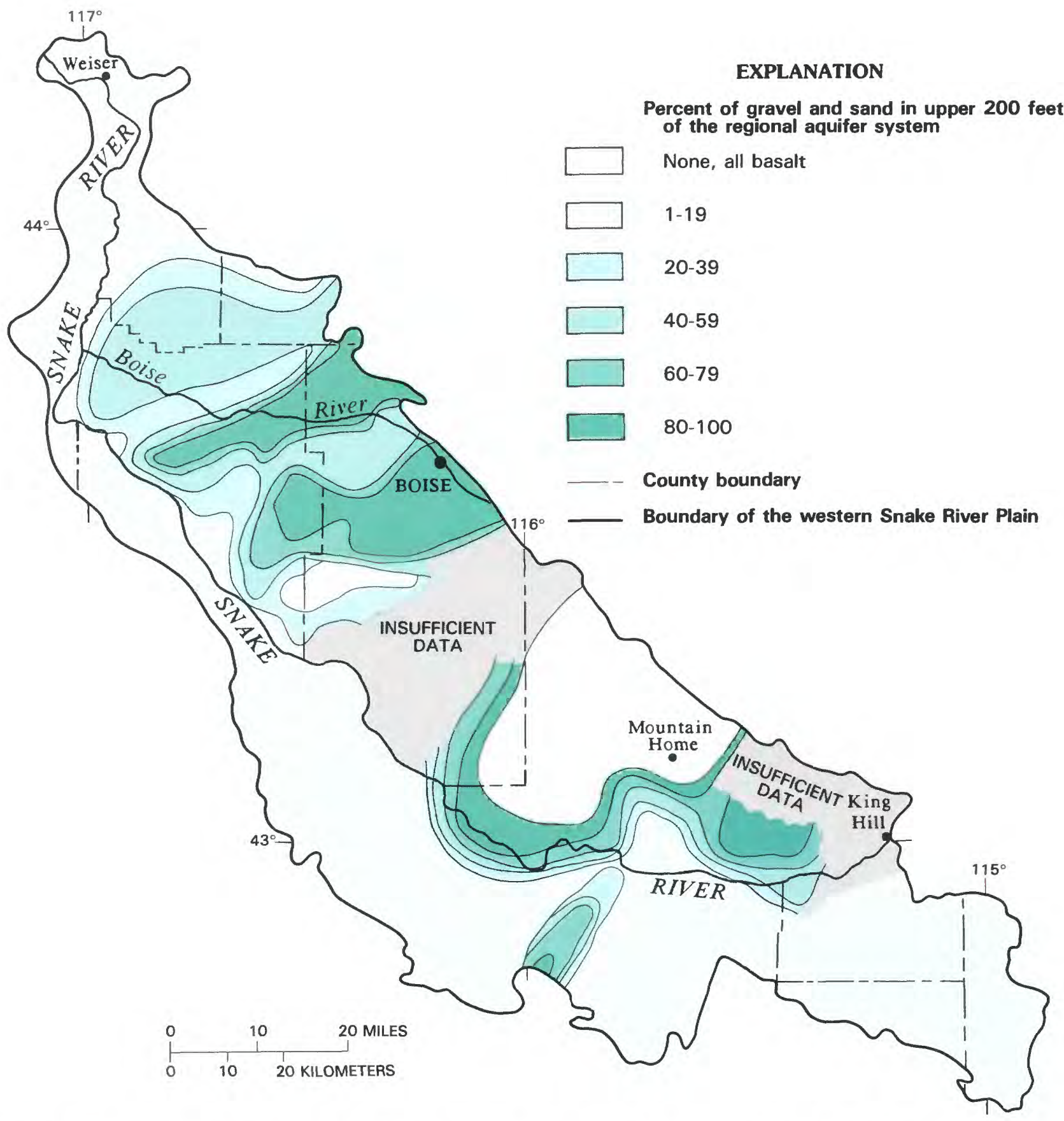

Figure 9.-Percentage of coarse-grained sedimentary rocks in upper 200 feet of the western Snake River Plain regional aquifer system. 
Geothermal water is produced from confined aquifers in Owyhee and Ada Counties; most wells are completed in rocks of the Idavada Volcanics. Some geothermal wells were drilled at sites of hot or warm springs and many flow at land surface.

\section{EASTERN PLAIN}

Layered basalt flows in the eastern Snake River Plain, chiefly Quaternary basalt of the Snake River Group, contain and yield exceptionally large volumes of water to wells and springs. Numerous thin flows with hydraulically connected interflow zones characterize the basalt aquifer. Saturated thickness (pl. 3) is greatest in the central part of the eastern plain and thins toward the margins where alluvium is interbedded with the basalt. Alluvium is thickest at the mouths of drainage basins tributary to the plain and generally extends only a few miles from the margins. Thin clay zones are interbedded with the basalt in many areas.

\section{HYDRAULIC CHARACTERISTICS OF QUATERNARY BASALT AND ALLUVIAL AQUIFERS}

Transmissivity of Quaternary basalt, as determined from aquifer tests, commonly exceeds $100,000 \mathrm{ft}^{2} / \mathrm{d}$ and, in places, 1 million $\mathrm{ft}^{2} / \mathrm{d}$ (table 4 ). Garabedian (1986, p. 17) obtained similar but generally higher values for much of the eastern plain on the basis of digital modeling (fig. 11). The model was most sensitive to changes in transmissivity and recharge values. Transmissivity values obtained from aquifer tests are generally lower than those determined from the model because wells tested were partially penetrating, whereas modeled transmissivities apply to the entire saturated thickness.

Yields of wells completed in basalt of the Snake River Group are among the largest in the Nation. Irrigation wells open to less than $100 \mathrm{ft}$ of the aquifer yield as much as $7,000 \mathrm{gal} / \mathrm{min}$ with only a few feet of drawdown; yields of 2,000 to $3,000 \mathrm{gal} / \mathrm{min}$ are common.

\section{EXPLANATION}

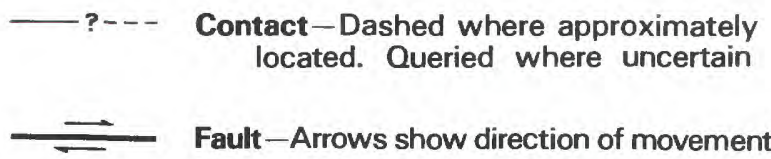

SOUTH

Fault-Arrows show direction of movement

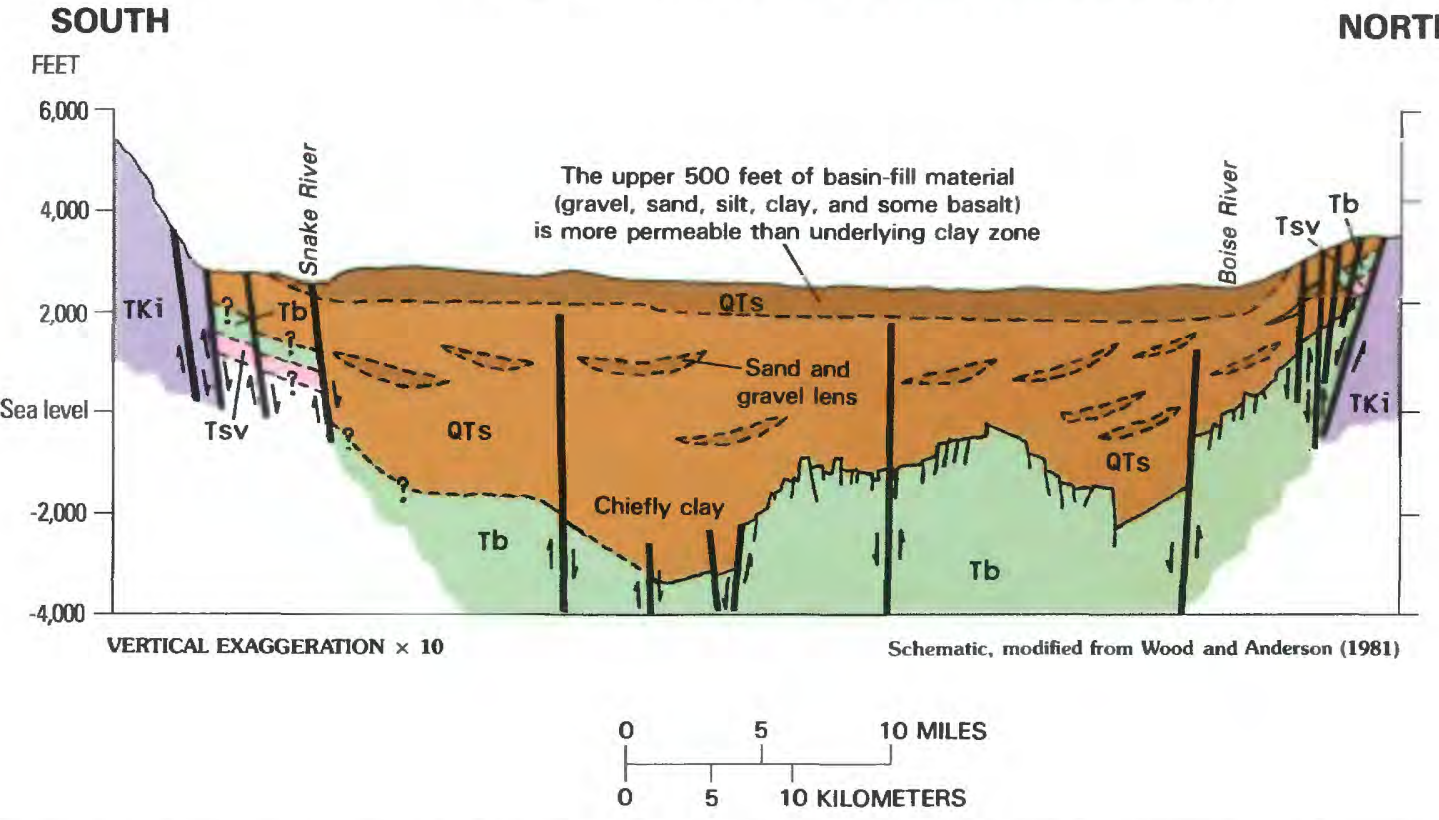

FigURE 10.-Schematic cross section showing relation of fine- and coarse-grained sedimentary rocks, western Snake River Plain. QTs, older alluvium; Tb, older basalt; Tsv, older silicic volcanic rocks; TKi, intrusive rocks. See plate 1 for description of map units. Owing to scale, some thin surficial deposits shown on plate 1 are not shown on cross section. 
TABLE 4.-Transmissivities and storage coefficients determined from aquifer tests, Snake River Plain

[Transmissivity in thousands of feet squared per day; duration of test in hours; -, no data available. Modified from Mundorff and others (1964, p. 147-155) and Nace and others (1959, p. 83)]

\begin{tabular}{|c|c|c|c|c|c|c|}
\hline County & Well number & Aquifer ${ }^{1}$ & $\begin{array}{c}\text { Duration } \\
\text { of test }\end{array}$ & Transmissivity & $\begin{array}{r}\text { Storage } \\
\text { coefficier }\end{array}$ & \\
\hline Jefferson & 8N-34E-11DC1 & $\mathrm{Qb}$ & 74 & ${ }^{2} 1,800$ & 0.013 to & 0.076 \\
\hline Jefferson & $7 \mathrm{~N}-34 \mathrm{E}-24 \mathrm{AA} 1$ & $\mathrm{Qb}$ & 74 & ${ }^{2} 610$ & .017 & \\
\hline Madison & $7 \mathrm{~N}-38 \mathrm{E}-23 \mathrm{DB} 1$ & $\mathrm{Qb}$ & 3 & 1,600 & .000017 & \\
\hline Butte & $6 \mathrm{~N}-31 \mathrm{E}-13 \mathrm{AC} 1$ & $\mathrm{Qb}$ & 24 & ${ }^{2} 110$ & .01 & \\
\hline Butte & $6 \mathrm{~N}-31 \mathrm{E}-13 \mathrm{AC} 2$ & $Q b$ & - & 110 & .03 & \\
\hline Butte & $6 \mathrm{~N}-31 \mathrm{E}-22 \mathrm{CC} 1$ & $\mathrm{Qb} / \mathrm{s}$ & - & 4 & - & \\
\hline Jefferson & $6 \mathrm{~N}-35 \mathrm{E}-26 \mathrm{CC} 1$ & $\mathrm{Qb}$ & 80 & ${ }^{2} 600$ & - & \\
\hline Canyon & $5 \mathrm{~N}-4 \mathrm{~W}-28 \mathrm{CC} 1$ & QTs & - & 43 & .025 & \\
\hline Butte & $5 \mathrm{~N}-31 \mathrm{E}-10 \mathrm{CD} 1$ & $\mathrm{Qb} / \mathrm{s}$ & - & 76 & - & \\
\hline Canyon & $4 \mathrm{~N}-3 \mathrm{~W}-25 \mathrm{DA} 1$ & QTs & - & 27 & .004 & \\
\hline Ada & $4 \mathrm{~N}-1 \mathrm{~W}-13 \mathrm{DC} 1$ & QTs & - & 7 & - & \\
\hline Ada & $4 \mathrm{~N}-1 \mathrm{~W}-13 \mathrm{DC} 2$ & QTs & - & 16 & .001 & \\
\hline Butte & $4 \mathrm{~N}-26 \mathrm{E}-32 \mathrm{BC} 1$ & $\mathrm{Qb}$ & - & 98 & .024 & \\
\hline Butte & $4 \mathrm{~N}-30 \mathrm{E}-7 \mathrm{AD} 1$ & $\mathrm{Qb}$ & 24 & 230 & - & \\
\hline Butte & $4 \mathrm{~N}-30 \mathrm{E}-30 \mathrm{AA} 1$ & $\mathrm{Qb}$ & 12 & 200 & - & \\
\hline Butte & 4N-30E-30AA2 & $\mathrm{Qb}$ & 46 & ${ }^{2} 110$ & - & \\
\hline Butte & $4 \mathrm{~N}-30 \mathrm{E}-30 \mathrm{AD} 1$ & $\mathrm{Qb}$ & 48 & ${ }^{2} 540$ & - & \\
\hline Canyon & $3 N-3 W-3 B B 1$ & QTs & - & 130 & - & \\
\hline Canyon & $3 N-3 W-11 D A 1$ & QTs & - & 160 & .0006 & \\
\hline Canyon & $3 \mathrm{~N}-2 \mathrm{~W}-8 \mathrm{CC} 1$ & QTs & - & 18 & .0006 & \\
\hline Canyon & $3 \mathrm{~N}-2 \mathrm{~W}-9 \mathrm{DD} 4$ & QTs & - & 37 & .0001 & \\
\hline Canyon & $3 \mathrm{~N}-1 \mathrm{~W}-7 \mathrm{BB} 1$ & QTs & - & 22 & .003 & \\
\hline Ada & $3 \mathrm{~N}-1 \mathrm{E}-5 \mathrm{AB} 1$ & QTs & - & 25 & .001 & \\
\hline Ada & $3 \mathrm{~N}-1 \mathrm{E}-36 \mathrm{AD} 2$ & QTs & - & 36 & .00007 & \\
\hline Ada & $3 \mathrm{~N}-2 \mathrm{E}-25 \mathrm{BB} 1$ & QTs & - & 17 & .30 to & .35 \\
\hline Butte & $3 \mathrm{~N}-29 \mathrm{E}-14 \mathrm{AC} 1$ & $\mathrm{Qb}$ & 46 & 1,900 & .02 & \\
\hline Butte & $3 \mathrm{~N}-29 \mathrm{E}-14 \mathrm{AD} 1$ & $\mathrm{Qb}$ & - & 2,400 & .06 & \\
\hline Butte & $3 \mathrm{~N}-29 \mathrm{E}-24 \mathrm{AD} 1$ & $\mathrm{Qb}$ & 24 & 440 & .06 & \\
\hline Butte & $3 \mathrm{~N}-30 \mathrm{E}-34 \mathrm{BA} 1$ & $\mathrm{Qb} / \mathrm{s}$ & 4 & 16 & - & \\
\hline Canyon & $2 \mathrm{~N}-1 \mathrm{~W}-7 \mathrm{BC} 4$ & $\mathrm{Qb} / \mathrm{s}$ & - & 230 & .004 & \\
\hline Butte & $2 \mathrm{~N}-29 \mathrm{E}-1 \mathrm{DB} 1$ & $\mathrm{Qb} / \mathrm{s}$ & 3 & 21 & - & \\
\hline Bonneville & $1 \mathrm{~N}-36 \mathrm{E}-1 \mathrm{CC} 1$ & $\mathrm{Qb}$ & 7 & 2,000 & .075 & \\
\hline Lincoln & $5 \mathrm{~S}-17 \mathrm{E}-26 \mathrm{AC} 1$ & $\mathrm{Qb}$ & 24 & 580 & .0002 & \\
\hline Lincoln & $6 \mathrm{~S}-18 \mathrm{E}-7 \mathrm{BC} 1$ & $\mathrm{Qb}$ & 8 & 460 & - & \\
\hline Jerome & 7S-19E-19AA1 & $\mathrm{Qb}$ & 8 & 1,200 & - & \\
\hline Gooding & $8 \mathrm{~S}-15 \mathrm{E}-33 \mathrm{CC} 1$ & $\mathrm{Qb}$ & 4 & 1,300 & .045 & \\
\hline Jerome & 8S-19E- 5DA1 & $\mathrm{Qb}$ & 8 & 670 & - & \\
\hline Minidoka & 8S-24E- 8AD2 & $\mathrm{Qb}$ & 4 & 1,200 & .014 & \\
\hline Jerome & 9S-19E-25BB1 & $\mathrm{Qb}$ & 8 & 370 & - & \\
\hline Cassia & 10S-21E-34DD1 & $\mathrm{Qb}$ & 25 & 840 & .22 & \\
\hline
\end{tabular}

${ }^{1} \mathrm{Qb}$, basalt; $\mathrm{Qb} / \mathrm{s}$, basalt and sediments; QTs, older alluvium.

${ }^{2}$ Average of two or more aquifer tests.

Locally, hydraulic characteristics of basalt and rate and direction of water movement vary widely within a short distance. On a larger scale, effects of local heterogeneity may be minimized and approximate hydrologic characteristics of basalt aquifers may be obtained by assuming homogeneous conditions.

Transmissivity of basalt of the Snake River Group is generally much higher than transmissivity of alluvial deposits (table 4). However, basalt transmissivity, as determined from aquifer tests, is anomalously low in places. Transmissivity is low where the tested interval is a relatively dense section of basalt with few or no interflow zones or where the tested interval contains numerous or thick clay layers, such as in well $6 \mathrm{~N}-31 \mathrm{E}-22 \mathrm{CC} 1$ in Butte County. Transmissivity of the older alluvium varies greatly, as indicated by tests at wells $3 \mathrm{~N}-$ $3 \mathrm{~W}-11 \mathrm{D}$ and $4 \mathrm{~N}-1 \mathrm{~W}-13 \mathrm{DC} 2$ (table 4). Thick sand 


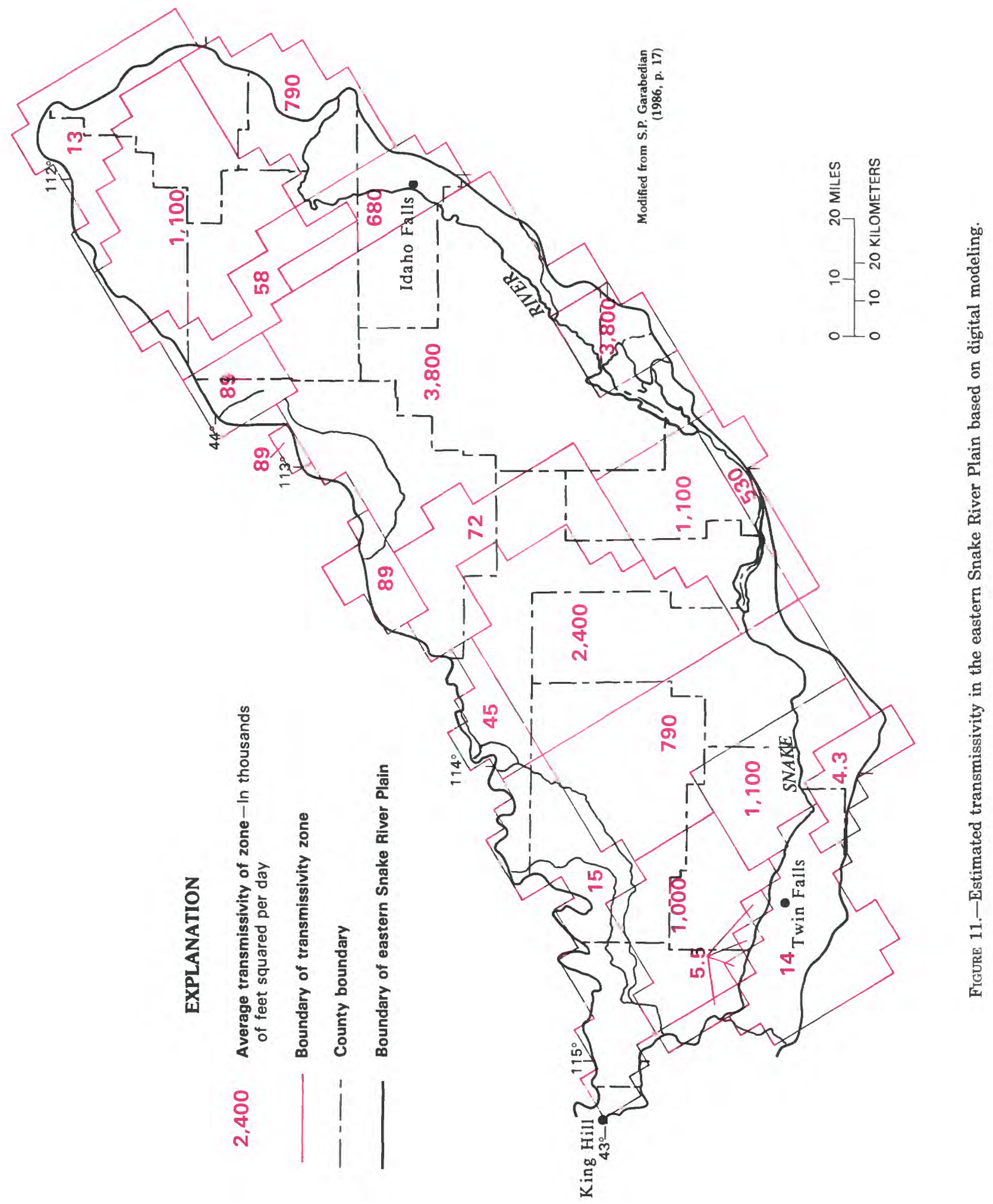


TABLE 5.-Specific-capacity data and calculated transmissivity, by county

\begin{tabular}{|c|c|c|c|c|c|c|c|}
\hline \multirow[b]{2}{*}{ County } & \multirow[b]{2}{*}{$\begin{array}{l}\text { Number } \\
\text { of wells }\end{array}$} & \multicolumn{5}{|c|}{ Specific capacity, in gallons per day per foot of drawdown 1} & \multirow[b]{2}{*}{$\begin{array}{l}\text { Calculated } \\
\text { transmissivity } \\
\left(\mathbf{x} 1,000 \mathrm{ft}^{2} / \mathrm{d}\right)\end{array}$} \\
\hline & & Mean & $\begin{array}{l}\text { Standard } \\
\text { deviation }\end{array}$ & Maximum & Minimum & Median & \\
\hline \multicolumn{8}{|l|}{ Idaho } \\
\hline Ada & 239 & 62 & 290 & 3,600 & 0.037 & 8.3 & 10 \\
\hline Bannock & 29 & 180 & 580 & 3,000 & .086 & 12 & 33 \\
\hline Bingham & 29 & 440 & 340 & 3,800 & 2.5 & 81 & 87 \\
\hline Blaine & 11 & 8.1 & 11 & 30 & .10 & 3.1 & 1.1 \\
\hline Bonneville & 14 & 740 & 1,000 & 3,600 & 5.5 & 400 & 150 \\
\hline Butte & 17 & 430 & 980 & 3,600 & 2.7 & 47 & 85 \\
\hline Canyon & 240 & 37 & 120 & 1,500 & .088 & 11 & 5.9 \\
\hline Cassia & 52 & 260 & 530 & 2,900 & .80 & 36 & 49 \\
\hline Clark & 3 & $\mathbf{5 3}$ & 25 & 75 & 26 & 58 & 8.8 \\
\hline Elmore & 99 & 210 & 800 & 5,000 & .014 & 15 & 39 \\
\hline Fremont & 13 & 77 & 230 & 830 & 2.0 & 10 & 13 \\
\hline Gem & 18 & 5.0 & 7 & 24 & .017 & 2.9 & .64 \\
\hline Gooding & 12 & 460 & 470 & 1,800 & 6.0 & $\mathbf{4 5 0}$ & 91 \\
\hline Jefferson & 39 & 1,300 & 1,500 & 7,200 & 10 & 730 & 280 \\
\hline Jerome & 52 & 440 & 540 & 1,800 & 5.0 & 180 & 87 \\
\hline Lincoln & 9 & 580 & 860 & 2,700 & 4.0 & 450 & 120 \\
\hline Madison & 21 & 700 & 820 & 2,400 & 1.0 & 290 & 140 \\
\hline Minidoka & 34 & 610 & 740 & $\mathbf{3 , 5 0 0}$ & .30 & 420 & 120 \\
\hline Owyhee & 90 & 120 & 530 & 3,000 & .017 & 3.6 & 21 \\
\hline Payette & 33 & 15 & 33 & 160 & .094 & 1.3 & 2.2 \\
\hline Power & 34 & 200 & 400 & 1,800 & .91 & 68 & 37 \\
\hline Twin Falls & 21 & 49 & 170 & 780 & .35 & 3.6 & 8.0 \\
\hline Washington & 9 & 2.1 & 5 & 16 & .0094 & .25 & .24 \\
\hline \multicolumn{8}{|l|}{ Oregon } \\
\hline Malheur & 47 & 13 & 30 & 200 & .0039 & 5.6 & 1.9 \\
\hline
\end{tabular}

${ }^{1}$ Rounded to two significant figures.

2Based on mean specific capacity and equations of Theis and others (1963, p. 331).

Assumptions: Well radius, $0.5 \mathrm{ft}$; storage coefficient, 0.15 ; time (duration), $0.083 \mathrm{~d}(2 \mathrm{~h}$ ).

and gravel deposits included in the alluvium may be highly transmissive.

Storage coefficients determined from aquifer tests also vary widely, as shown in table 4 . Values given indicate that aquifers range from unconfined to confined; older alluvium usually has the lowest values, but there are exceptions. Owing to the heterogeneity of basalt and intercalated sedimentary rocks, ground water is confined in places, as suggested by low storage coefficients.

Because aquifer tests have been few and widely scattered, the more readily available specific-capacity data were used to estimate transmissivity throughout the plain by a method of Theis and others $(1963, p$. 331). Specific-capacity data, summarized by county and listed in table 5, were obtained from drillers' logs and aquifer tests. Transmissivities in table 5 were calculated using the mean specific capacity for each county. In general, calculated values show some agreement with aquifer test values in table 4 . Comparison (by county) of average transmissivities determined from aquifer tests with those estimated from specificcapacity data shows that the latter are lower by as much as an order of magnitude. Although the difference is seemingly large, values estimated from specific capacity give at least a general indication of an aquifer's ability to transmit water. Most wells for which specific-capacity data are available are partially penetrating; therefore, estimated transmissivities are lower than for fully penetrating wells. In addition, losses in the pumped well cause transmissivities estimated from specific-capacity data to be lower than transmissivities obtained from aquifer tests that included observation wells.

\section{GEOLOGIC CONTROLS ON GROUND-WATER MOVEMENT}

As a whole, the regional aquifer system in the eastern Snake River Plain behaves as an unconfined system, although locally, interbedded clay layers and 
dense, unfractured basalt cause semiconfined conditions. In the western plain, water in many sand and gravel aquifers is confined by clay layers.

Wells drilled near faults along the margins of the plain, chiefly the western plain, commonly produce geothermal water. Faults in these areas are important avenues for the vertical movement of water (Chapman and Ralston, 1970, p. 4; Lewis and Young, 1982 , p. 22). Alternatively, faults may impede or change the direction of horizontal ground-water movement (Lewis and Goldstein, 1982, p. 39; Lewis and Young, 1982, p. 6). Upward leakage of geothermal water recharges overlying basalt and sedimentary-rock aquifers containing cold water.

\section{QUATERNARY BASALT AQUIFERS}

The physical characteristics of the Quaternary basalt govern the amount of water in storage and rates of ground-water recharge and discharge.

Water moves horizontally through porous and permeable interflow zones in basalt aquifers. An interflow zone consists of highly fractured vesicular basalt and cinders that compose the top part of one flow and the base of the overlying flow. Horizontal water movement in the rest of a basalt flow is probably several orders of magnitude less than in the interflow zone. Water in the basalt moves vertically along joints and faults. Vertical movement is dependent chiefly on the degree of fracturing and the presence or absence of sedimentary interbeds that may impede water movement.

Layers of dense basalt with extremely low hydraulic conductivity may act as a confining bed and cause anomalous water levels in some areas. In such areas, water may first enter a drill hole several feet to several tens of feet below the expected water table. This may be the reason for some reported dry holes in basalt of the Snake River Group. When a deeper zone of high hydraulic conductivity is penetrated, the water level in the hole may rise. The amount of rise is generally less than $5 \mathrm{ft}$ but can be more than $50 \mathrm{ft}$ (Nace and others, 1959, p. 48). Well A (fig. 12) is drilled into the dense, unfractured central part of a flow and is dry. Well $\mathrm{B}$, however, is drilled through the central part of a flow (where little water is present) and into fractured, highly transmissive basalt. The water level in well $B$ will rise to about the level of the regional water table. Such was the case during the drilling of a test hole at site $2 \mathrm{~N}-27 \mathrm{E}-23 \mathrm{AC} 2$. The 1,000-ft hole was completed in dense basalt and remained dry for 13 months (Nace and others, 1959, p. 49). The hole subsequently was deepened to 1,065 $\mathrm{ft}$, and water in the hole rose to $981 \mathrm{ft}$ below land surface.

Pillow lavas typically have the highest hydraulic conductivity. Most were formed in lava-dammed lakes that filled ancestral canyons of the Snake River. Highly permeable pillow lava in ancestral canyons is intersected by the present-day Snake River canyon between King Hill and Milner. Included in the reach are some of the Nation's largest springs (Thousand Springs area, fig. 1), which discharged about $6,000 \mathrm{ft}^{3} / \mathrm{s}$ in 1980 (Kjelstrom, 1986). H.R. Covington (U.S. Geological Survey, written commun., 1984) mapped the north wall of the Snake River canyon between King Hill and Milner as part of the RASA study (pl. 2). He verified that the largest springs issue at various altitudes from pillow lavas in ancestral Snake River canyons.

In places, the springs issue from the canyon wall at the contact between Quaternary basalt of the Snake River Group and underlying Idaho Group sedimentary rocks of low hydraulic conductivity; elsewhere, springs issue at the contact between basalt of the Snake River Group and Tertiary Banbury Basalt of the Idaho Group.

In the vicinity of Thousand Springs (segment 7-8, pl. 2), sedimentary rocks of the Idaho Group (Glenns Ferry Formation) crop out in the north canyon wall and extend several miles northeastward beneath the Quaternary basalt. A 200-ft-thick layer of Idaho Group sedimentary rocks (clay, sand, and gravel) was penetrated in the RASA test hole. The presence of similar

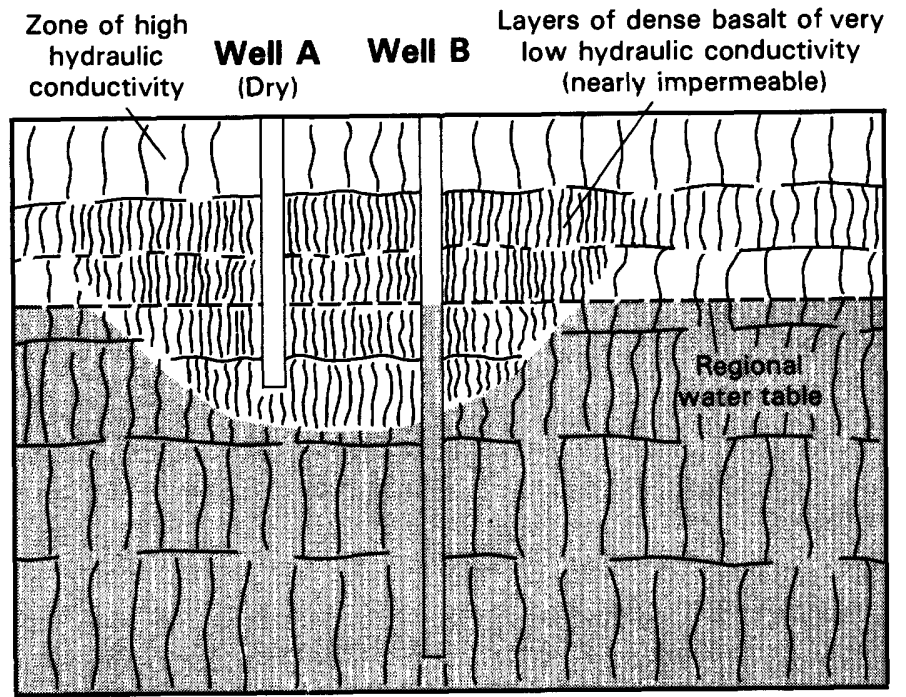

Figure 12.-Effect of dense basalt layers on ground-water levels in a hypothetical flow of basalt of the Snake River Group. Drawing not to scale. 
types of rocks in several other drill holes in the Thousand Springs area indicates that sedimentary rocks of the Idaho Group may be areally extensive in the western part of the eastern plain. Therefore, in the Thousand Springs area, sedimentary rocks constitute the base of the Quaternary basalt aquifer in places. The steeper water-table gradient in this part of the Snake River Plain is attributed to lower transmissivity caused by thinning of the basalt aquifer. The underlying sedimentary rocks are less transmissive and are confining in places (Lindholm and others, 1983).

In the RASA test hole (fig. 4), hydraulic head in the upper part of the Banbury Basalt $(670 \mathrm{ft}$ below land surface) is about $65 \mathrm{ft}$ higher than the water table in the basalt of the Snake River Group (260 ft below land surface). The thick sedimentary zone that separates the two basalt units is the confining layer. Increases in hydraulic head are more pronounced at greater depths. Hydraulic head in the Banbury Basalt sequence $(1,100 \mathrm{ft}$ below land surface) is about $155 \mathrm{ft}$ higher than the water table in the Snake River Group.
Some water in the Banbury Basalt may be from the geothermal system in the underlying Idavada Volcanics.

Semiconfined aquifers respond to external stresses such as atmospheric pressure changes, earthquake waves, and pumping, similar to a confined system. Where the unsaturated zone is capped by confining layers, some uncased wells expel or draw in air when atmospheric pressure differs from the air pressure in the unsaturated zone (fig. 13). The exchange of air continues until a pressure equilibrium is reached. The exchange of air in wells is common in the eastern Snake River Plain where many wells are uncased, a situation that allows air entering the well bore to penetrate a considerable distance in the unsaturated basalt surrounding the well.

Atmospheric pressure changes may affect water levels by several tenths of a foot (fig. 14); accordingly, water-level measurements must be adjusted to interpret aquifer tests properly. Adjustments are particularly necessary when (1) barometric (atmospheric)

\section{EXPLANATION}

\section{$P_{1} \quad$ Atmospheric pressure \\ $P_{2} \quad$ Unsaturated zone pressure below semiconfining layers}

LOW ATMOSPHERIC PRESSURE

Air is expelled from well
HIGH ATMOSPHERIC PRESSURE

Air is drawn into well

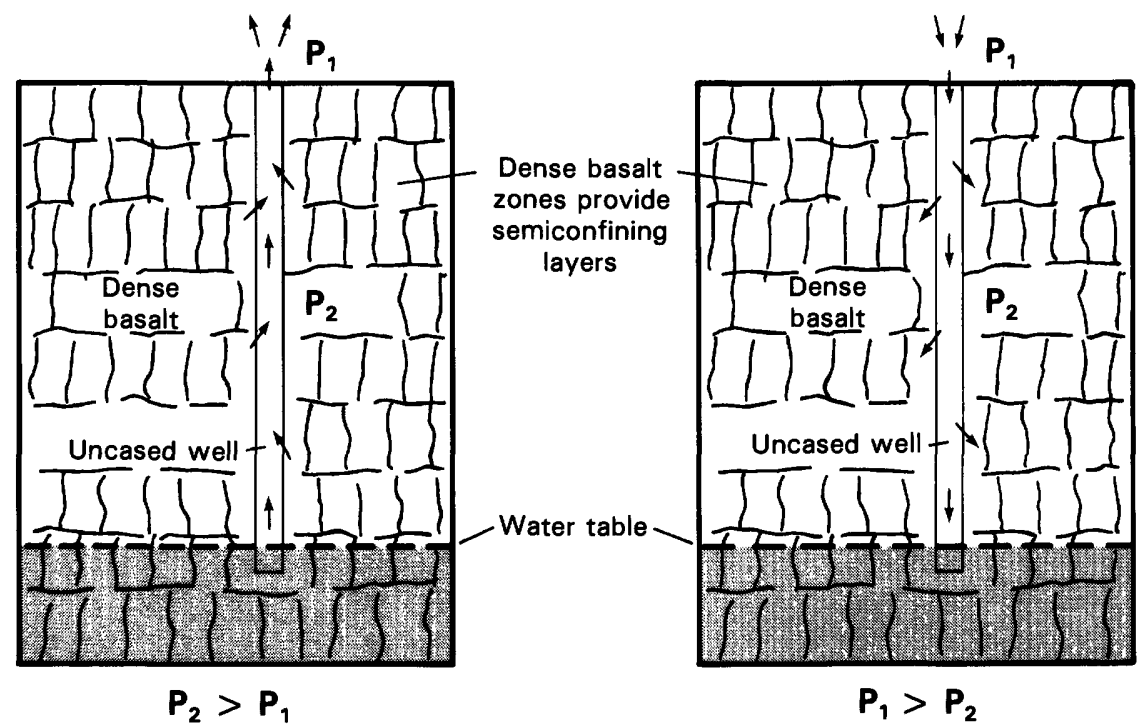

FIGURE 13.-Effects of atmospheric pressure changes on air movement in the unsaturated zone. Drawing not to scale. 
pressure changes are large, (2) water-level changes are small, and (3) the aquifer has a high barometric efficiency (Mundorff and others, 1964, p. 49). Truly confined aquifers usually have the highest barometric efficiencies. E.H. Walker (U.S. Geological Survey, written commun., 1963) reported that barometric pressure efficiencies of 80 to 100 percent are common in basalt of the Snake River Group during the first few hours of an atmospheric pressure change. However, in many instances, the water-level response tends to decrease with time after the atmospheric pressure changes.

The uneven surface of basalt flows caused by differential cooling and overlapping of flows from adjacent sources creates areas of internal drainage in which water ponds, evaporates, or percolates to the water table. Ponded water may be from direct precipitation, runoff, or irrigation water. Disposal wells are used to drain some of these areas.

\section{TERTIARY SILICIC VOLGANIC AND BASALT AQUIFERS}

Hydraulic conductivity of Tertiary silicic volcanic rocks is generally low relative to that of Quaternary

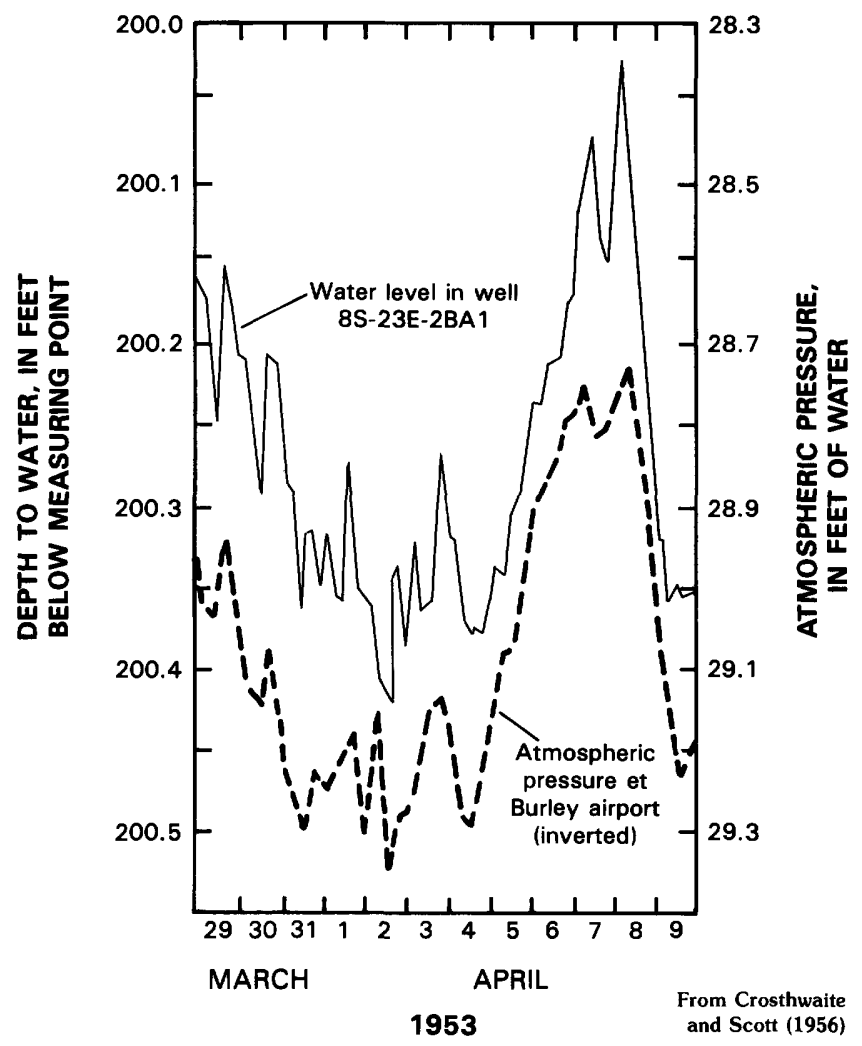

FigURE 14.-Effects of atmospheric pressure changes on water level in well 8S-23E-2BA1. basalt. Pleistocene silicic volcanic rocks at the northeastern end of the plain (pl. 1; geologic cross section $F-F^{\prime}$, pl. 3) are an exception. Water movement in silicic volcanic rocks is controlled largely by fractures. Although. not considered part of the Snake River Plain regional aquifer system, silicic volcanic rocks are aquifers in many areas near the margins of the plain.

Hydraulic conductivity of Tertiary basalt (mainly Banbury Basalt of the Idaho Group) varies widely but generally is much less than that of Quaternary basalt. As seen in outcrops and cores, primary and secondary porosity of the Banbury Basalt and, consequently, hydraulic conductivity commonly are reduced by secondary mineralization. Because Tertiary basalt flows are usually much thicker than Quaternary flows, interflow zones within a given thickness are fewer and transmissivity is lower. In a 10,365-ft test hole at the Idaho National Engineering Laboratory (fig. 1), transmissivity of the Quaternary basalt was estimated to be 1,000 to 10,000 times greater than that of the Tertiary basalt (J.T. Barraclough, U.S. Geological Survey, written commun., 1979). The degree of hydraulic connection between Tertiary and Quaternary basalts is largely unknown in much of the plain. Outside the margins of the Snake River Plain, Tertiary basalt is an important aquifer.

\section{SUMMARY}

Rocks underlying the Snake River Plain form the framework for a regional ground-water system that supplies large quantities of water for irrigation. For study purposes, the Snake River Plain was divided into eastern and western parts on the basis of rock type and hydrology. The eastern plain is underlain by predominantly basaltic rocks, the western plain by unconsolidated sedimentary rocks.

The western part of the Snake River Plain is a graben with distinct fault zones along its margins. Faults bordering the eastern part of the plain are not exposed at land surface and are defined chiefly by geophysical methods. The Snake River Plain is an uncommon structural feature in the Earth's crust. Holocene volcanism, open fissures, and continued subsidence indicate that the plain is an active structure; development of the plain began in middle Miocene time. Several theories concerning the plain's origin have been presented, no one of which is in agreement with all known geological and geophysical data. As a result of geological and geophysical modeling studies, several new ideas concerning the plain's origin have 
been proposed. A volcanotectonic evolution model relates forces associated with movements of the North American and Pacific plates to the formation of the plain. The Snake River Plain appears to be a transitional transform boundary zone of the Great Basin, created by oblique extensional forces.

The oldest known rocks underlying the plain are of middle Miocene age. Miocene volcanic rocks at the plain's margin were intensely faulted and severely eroded before the plain was formed. Deep crustal structure of the plain has been described by geophysical studies, but little detailed work has been done to describe structure and distribution of major rock types in the upper few thousand feet.

An unnamed group of silicic volcanic rocks of middle Miocene age underlies the Payette Formation and the Columbia River Basalt Group in the western plain. In the eastern plain, the unnamed silicic volcanic rocks underlie the Walcott Tuff, Starlight Formation, and Salt Lake Formation. The Idavada Volcanics, Starlight Formation, and Walcott Tuff overlie the Columbia River Basalt Group and older sedimentary rocks of the Salt Lake Formation. The Idaho Group and its basal formations, the Banbury Basalt and Poison Creek Formation, overlie the Idavada Volcanics and the Salt Lake Formation. They, in turn, are overlain by basalt of the Snake River Group and terrace gravels.

A 90-mi reach of the north Snake River canyon wall from King Hill to Milner was mapped to determine geologic controls on springs and to define geohydrologic relations. The stratigraphic sequence in the canyon, in the vicinity of Thousand Springs, is similar to that in the RASA test hole about $10 \mathrm{mi}$ northeast of the canyon.

The chiefly unconsolidated sedimentary rocks in the western plain are as much as $5,000 \mathrm{ft}$ thick; basalt of the Snake River Group in the eastern plain may be equally thick. Near the margins of the eastern plain, sedimentary rocks are intercalated with basalt. A thick sedimentary layer of the Idaho Group separates basalt of the Snake River Group from the Banbury Basalt of the Idaho Group in parts of the eastern plain. Where sedimentary rocks are absent, separation was made on the basis of greater secondary mineralization in the Banbury Basalt.

Electrical resistivity soundings and gravity modeling helped define distribution of major rock units. Electrical resistivity data were especially helpful in estimating the thickness of Quaternary basalt, which is the major rock unit in the Snake River Plain regional aquifer system.

Pleistocene and Holocene sand and gravel aquifers in the Boise River flood plain and along the northern margin of the western plain are highly transmissive. During the Pleistocene Epoch, sediment was repeatedly washed onto the plain from bordering mountains to the north. The percentage of coarse-grained sedimentary deposits decreases to the southwest, where fine-grained sedimentary deposits predominate. Discontinuous lenses of sand and gravel within the fine-grained sedimentary deposits yield small to moderate quantities of water to wells. A basalt aquifer near Mountain Home is highly transmissive. Wells drilled along the margin of the western plain penetrate faults that transmit geothermal water from underlying Tertiary silicic volcanic rock aquifers. These aquifers usually are confined, and wells completed in them commonly flow at land surface.

Most ground-water movement in layered basalts is horizontal through highly porous and permeable interflow zones. Vertical water movement is considerably restricted and is dependent on degree of fracturing and presence or absence of fine-grained intercalated sedimentary rocks that may impede movement. Numerous thin flows and, consequently, many hydraulically connected interflow zones characterize the basalt aquifer in the eastern plain. The basalt aquifer is thickest in the central part of the eastern plain and thins toward the margins, where sand and gravel aquifers also provide adequate supplies of water to wells. Clay layers within the sedimentary sequence are confining in places, as is dense basalt.

Transmissivity of basalt of the Snake River Group, as determined from aquifer tests, commonly exceeds $100,000 \mathrm{ft}^{2} / \mathrm{d}$ and, in places, 1 million $\mathrm{ft}^{2} / \mathrm{d}$. Yields of wells completed in basalt of the Snake River Group are some of the largest in the Nation. Wells open to less than $100 \mathrm{ft}$ of the aquifer yield as much as $7,000 \mathrm{gal} / \mathrm{min}$; yields of 2,000 to 3,000 $\mathrm{gal} / \mathrm{min}$ with only a few feet of drawdown are common. However, owing to the heterogeneity of basalt, not all wells are as successful. In areas of thick flows and dense basalt, well yields may be low.

The aquifer in basalt of the Snake River Group, as a whole, behaves as an unconfined system, but clay layers and dense, unfractured basalt are locally confining. Layers of dense basalt with extremely low hydraulic conductivity may be confining and cause anomalous water levels in some areas. Even though the regional water table is at a relatively uniform altitude in these areas, a well may have to be drilled several tens of feet below that water-table altitude before reaching a permeable zone. Water will then rise in the well to an altitude about the same as that of the regional water table. 
Ancestral canyons of the Snake River were filled with highly permeable pillow lavas that are intersected by the present canyon. Some of the Nation's largest springs issue from pillow lavas in the north wall of the Snake River canyon. In 1980, groundwater discharge (largely spring flow) between Milner and King Hill averaged about $6,000 \mathrm{ft}^{3} / \mathrm{s}$. Springs are located at the contacts between highly transmissive basalt of the Snake River Group and less transmissive sedimentary rocks and Banbury Basalt of the Idaho Group.

Faults and fractures in the Idavada Volcanics and Banbury Basalt are permeable zones for water storage and conduits for water movement. Geothermal water issues from the Idavada Volcanics in fracture zones along the margins of the plain.

\section{REFERENCES CITED}

Anderson, J.E., and Wood, S.H., 1981, Chapter 3 of Geohydrology, Mitchell, J.C., ed., Geothermal investigations in Idaho, part 11, Geological, hydrological, geochemical, and geophysical investigations of the Nampa-Caldwell and adjacent areas, southwestern Idaho: Idaho Department of Water Resources, Water Information Bulletin 30, p. 33-42.

Berg, J.W., and Thiruvathuskal, J.K., 1967, Complete Bouguer gravity anomaly map of Oregon: Portland, Oregon Department of Geology and Mineral Resources, Map GMS-4B.

Bigelow, B.B., Goodell, S.A., and Newton, G.D., 1984, Pumpage for irrigation in 1980 on the Snake River Plain, Idaho and eastern Oregon: U.S. Geological Survey Open-File Report $84-434$, scale $1: 1,000,000,2$ sheets.

Bisdorf, R.J., 1983, Schlumberger soundings on the Snake River Plain near Nampa, Idaho: U.S. Geological Survey Open-File Report 83-412, 56 p.

Bond, J.G., and others, 1978, Geologic map of Idaho: Moscow, Idaho Bureau of Mines and Geology, scale 1:500,000.

Bonnichsen, Bill, and Breckenridge, R.M., eds., 1982, Cenozoic geology of Idaho: Moscow, Idaho Bureau of Mines and Geology Bulletin 26, $725 \mathrm{p}$.

Chapman, S.L., and Ralston, D.R., 1970, Ground-water resource of the Blue Gulch area in eastern Owyhee and western Twin Falls Counties, Idaho: Idaho Department of Water Administration, Water Information Bulletin 20, $36 \mathrm{p}$.

Christiansen, R.L., and McKee, E.H., 1978, Late Cenozoic volcanic and tectonic evolution of the Great Basin and Columbia intermontane region, in Smith, R.B., and Eaton, G.P., eds., Cenozoic tectonics and regional geophysics of the western cordillera: Geological Society of America Memoir 152, p. 283-311.

Crosthwaite, E.G., 1973, A progress report on results of test drilling and ground-water investigations of the Snake Plain aquifer, southeastern Idaho; Part 1, Mud Lake region 196970; Part 2, Observation wells south of Arco and west of Aberdeen: Idaho Department of Water Resources, Water Information Bulletin $32,60 \mathrm{p}$.

1974, A progress report on results of test drilling and ground-water investigations of the Snake Plain aquifer, southeastern Idaho, part 3, Lake Walcott-Bonanza Lake area: Boise, Idaho Department of Water Resources, Water Information Bulletin $38,25 \mathrm{p}$.

Crosthwaite, E.G., and Scott, R.C., 1956, Ground water in the North Side Pumping Division, Minidoka Project, Minidoka County, Idaho: U.S. Geological Survey Circular 371, 20 p.

deSonneville, J.L.J., 1974, Development of a digital groundwater model with application to aquifers in Idaho: Moscow, University of Idaho, Ph.D. thesis, $228 \mathrm{p}$.

Dobrin, M.B., 1952, Introduction to geophysical prospecting: New York, McGraw-Hill, 433 p.

Doherty, D.J., McBroome, L.A., and Kuntz, M.A., 1979, Preliminary geological interpretation and lithologic log of the exploratory geothermal test well (INEL-1), Idaho National Engineering Laboratory, eastern Snake River Plain, Idaho: U.S. Geological Survey Open-File Report 79-1248, 10 p.

Embree, G.F., McBroome, L.A., and Doherty, D.J., 1982, Preliminary stratigraphic framework of the Pliocene and Miocene rhyolite, eastern Snake River Plain, Idaho, in Bonnichsen, Bill, and Breckenridge, R.M., eds., Cenozoic geology of Idaho: Moscow, Idaho Bureau of Mines and Geology Bulletin 26 , p. 333-343.

Garabedian, S.P., 1986, Application of a parameter estimation technique to modeling the regional aquifer underlying the eastern Snake River Plain, Idaho: U.S. Geological Survey Water-Supply Paper 2278, 60 p.

Hamilton, Warren, and Myers, W.B., 1966, Cenozoic tectonics of the Western United States: Reviews of Geophysics, v. 4, p. 509-550.

Hayden, F.V., 1872, A report of progress of the exploration in Wyoming and Idaho for the year 1878: U.S. Geological and Geographical Survey of the Territories, Fifth Annual Report, $538 \mathrm{p}$.

Jackson, D.B., 1974, Report on direct current soundings over a geothermal prospect in the Bruneau-Grand View area, Idaho: U.S. Geological Survey Open-File Report 74-240, $43 \mathrm{p}$.

Kjelstrom, L.C., 1986, Flow characteristics of the Snake River and water budget for the Snake River Plain, Idaho and eastern Oregon: U.S. Geological Survey Hydrologic Investigations Atlas HA-680, scale 1:1,000,000, 2 sheets.

Kuntz, M.A., 1978, Geology of the Arco-Big Southern Butte area, eastern Snake River Plain, and volcanic hazards to the Radioactive Waste Management Complex and other waste storage and reactor facilities at the Idaho National Engineering Laboratory, Idaho, with a section on Statistical treatment of the age of lava flows, by J.O. Kork: U.S. Geological Survey Open-File Report 78-691, 70 p.

Kuntz, M.A., and Dalrymple, G.B., 1979, Geology, geochronology, and potential volcanic hazards in the Lava Ridge-Hells Half Acre area, eastern Snake River Plain, Idaho: U.S. Geological Survey Open-File Report 79-1657, 66 p.

Kuntz, M.A., Mabey, D.R., Champion, D.E., Stanley, W.D., Lefebvre, R.H., Spiker, E.C., McBroome, L.A., and Covington, H.R., 1983, Geologic and geophysical maps of the Great Rift instant study area, Blaine, Butte, Minidoka, and Power Counties, Idaho: U.S. Geological Survey Miscellaneous Field Studies Map MF-1462-A, scale 1:125,000, 2 sheets.

LaFehr, T.R., and Pakiser, L.C., 1962, Gravity, volcanism, and crustal deformation in the eastern Snake River Plain, Idaho: U.S. Geological Survey Professional Paper 450-D, p. D76D78.

Leeman, W.P., 1982, Development of the Snake River PlainYellowstone Plateau province, Idaho and Wyoming; An overview and petrologic model, in Bonnichsen, Bill, and 
Breckenridge, R.M., eds., Cenozoic geology of Idaho: Moscow, Idaho Bureau of Mines and Geology Bulletin 26, p. 155-177.

Lewis, B.D., and Goldstein, F.J., 1982, Evaluation of a predictive ground-water solute-transport model at the Idaho National Engineering Laboratory, Idaho: U.S. Geological Survey WaterResources Investigations 82-25, $71 \mathrm{p}$.

Lewis, R.E., and Young, H.W., 1982, Geothermal resources in the Banbury Hot Springs area, Twin Falls County, Idaho: U.S. Geological Survey Water-Supply Paper 2186, 27 p.

Lindgren, Waldemar, 1898, Boise [quadrangle], Idaho, folio 45 of Geologic atlas of the United States: U.S. Geological Survey, 4 pls.

Lindgren, Waldemar, and Drake, N.F., 1904a, Nampa [quadrangle], Idaho-Oregon, folio 103 of Geologic atlas of the United States: U.S. Geological Survey, 5 p.

1904b, Silver City [quadrangle], Idaho, folio 104 of Geologic atlas of the United States: U.S. Geological Survey, 6 p.

Lindholm, G.F., 1981, Plan of study for the regional aquifer system analysis of the Snake River Plain, Idaho and eastern Oregon: U.S. Geological Survey Open-File Report 81-689, 21 p.

Lindholm, G.F., Garabedian, S.P., Newton, G.D., and Whitehead, R.L., 1983, Configuration of the water table, March 1980, in the Snake River Plain regional aquifer system, Idaho and eastern Oregon: U.S. Geological Survey Open-File Report 82-1022, scale 1:500,000.

1986, Configuration of the water table and depth to water, spring 1980, water-level fluctuations, and water movement in the Snake River Plain regional aquifer system, Idaho and eastern Oregon: U.S. Geological Survey Open-File Report 86149 , scale 1:500,000.

Lindholm, G.F., and Goodell, S.A., 1986, Irrigated acreage and other land uses on the Snake River Plain, Idaho and eastern Oregon: U.S. Geological Survey Hydrologic Investigations Atlas HA-691, scale 1:500,000.

Love, J.D., Weitz, J.L., and Hose, R.K., 1952, Geologic map of Wyoming: U.S. Geological Survey, scale 1:500,000 (preliminary ed.).

Low, W.H., 1985, Solute distribution in ground and surface water in the Snake River basin, Idaho and eastern Oregon: U.S. Geological Survey Open-File Report 85-167, scale 1:500,000, 2 sheets.

Mabey, D.R., 1978, Regional gravity and magnetic anomalies in the eastern Snake River Plain, Idaho: U.S. Geological Survey Journal of Research, v. 6 , no. 5, p. 553-562.

1982, Geophysics and tectonics of the Snake River Plain, Idaho, in Bonnichsen, Bill, and Breckenridge, R.M., eds., Cenozoic geology of Idaho: Moscow, Idaho Bureau of Mines and Geology Bulletin 26, p. 139-153.

Mabey, D.R., Peterson, D.L., and Wilson, C.W., 1974, Preliminary gravity map of southern Idaho: U.S. Geological Survey OpenFile Report 74-78, scale 1:500,000.

Malde, H.E., 1959, Fault zone along northern boundary of western Snake River Plain, Idaho: Science, v. 130, no. 3370, p. 272.

1965, Snake River Plain, in The Quaternary of the United States: Princeton, N.J., Princeton University Press, p. 255263.

1968, The catastrophic late Pleistocene Bonneville flood in the Snake River Plain, Idaho: U.S. Geological Survey Professional Paper 596, $52 \mathrm{p}$.

1982, The Yahoo Clay, a lacustrine unit impounded by the McKinney Basalt in the Snake River canyon near Bliss, Idaho, in Bonnichsen, Bill, and Breckenridge, R.M., eds., Cenozoic geology of Idaho: Moscow, Idaho Bureau of Mines and Geology Bulletin 26, p. 617-628.
Malde, H.E., and Powers, H.A., 1962, Upper Cenozoic stratigraphy of the western Snake River Plain, Idaho: Geological Society of America Bulletin, v. 73, no. 10, p.1197-1219.

1972, Geologic map of the Glenns Ferry-Hagerman area, west-central Snake River Plain, Idaho: U.S. Geological Survey Miscellaneous Geologic Investigations Map I-696, scale 1:48,000, 2 sheets.

Mansfield, G.R., 1920, Geography, geology, and mineral resources of the Fort Hall Indian Reservation, Idaho: U.S. Geological Survey Bulletin $713,152 \mathrm{p}$.

-1927, Geography, geology, and mineral resources of part of southeastern Idaho: U.S. Geological Survey Professional Paper $152,53 \mathrm{p}$.

1929, Geography, geology, and mineral resources of the Portneuf quadrangle, Idaho: U.S. Geological Survey Bulletin 803,110 p.

Mantei, C.L., 1974, Snake Plain aquifer, Idaho electric analog studies: Denver, Colo., U.S. Bureau of Reclamation, Third Progress Report, 43 p. (unnumbered).

McIntyre, D.H., Ekren, E.B., and Hardyman, R.F., 1982, Stratigraphic and structural framework of the Challis Volcanics in the eastern half of the Challis $1^{\circ} \times 2^{\circ}$ quadrangle, Idaho, in Bonnichsen, Bill, and Breckenridge, R.M., eds., Cenozoic geology of Idaho: Moscow, Idaho Bureau of Mines and Geology Bulletin 26, p. 3-22.

Morgan, W.J., 1972, Deep mantle convection plumes and plate motions: American Association of Petroleum Geologists Bulletin, v. 56, p. 203-213.

Mundorff, M.J., Crosthwaite, E.G., and Kilburn, Chabot, 1964, Ground water for irrigation in the Snake River basin in Idaho: U.S. Geological Survey Water-Supply Paper 1654, 224 p.

Nace, R.L., Stewart, V.W., Walton, W.C., and others, 1959, Geography, geology, and water resources of the National Reactor Testing Station, Idaho, Part 3, Hydrology and water resources: U.S. Geological Survey Administrative Report, $253 \mathrm{p}$.

Nace, R.L., Voegeli, P.T., Jones, J.R., and Deutsch, Morris, 1975, Generalized geologic framework of the National Reactor Testing Station, Idaho: U.S. Geological Survey Professional Paper 725-B, 49 p.

Nace, R.L., West, S.W., and Mower, R.W., 1975, Feasibility of ground-water features of the alternate plan for the Mountain Home Project, Idaho: U.S. Geological Survey Water-Supply Paper 1376, 121 p.

Newton, G.D., 1978, Application of a simulation model to the Snake Plain aquifer: Moscow, University of Idaho, M.S. thesis, $82 \mathrm{p}$.

Norvitch, R.F., Thomas, C.A., and Madison, R.J., 1969, Artificial recharge to the Snake Plain aquifer; An evaluation of potential and effect: Idaho Department of Reclamation, Water Information Bulletin 12, $59 \mathrm{p}$.

Rebertson, J.B., Schoen, Robert, and Barraclough, J.T., 1974, The influence of liquid waste disposal on the geochemistry of water at the National Reactor Testing Station, Idaho, 1952-70: U.S. Geological Survey Open-File Report IDO-22053, 210 p.

Robinette, M.S., and Matzner, R.A., 1980, Electrical resistivity investigations of the Springfield-Blackfoot area, Idaho: U.S. Bureau of Water and Power Resources Service, Project Completion Report, 119 p.

Ress, C.P., and Forrester, J.D., 1958, Outline of the geology of Idaho: Moscow, Idaho Bureau of Mines and Geology Bulletin $15,74 \mathrm{p}$.

Russell, I.C., 1902, Geology and water resources of the Snake River Plains of Idaho: U.S. Geological Survey Bulletin 199, $192 \mathrm{p}$. 
1903a, Notes on the geology of southwestern Idaho and southeastern Oregon: U.S. Geological Survey Bulletin 217, $83 \mathrm{p}$.

$-1903 \mathrm{~b}$, Preliminary report on artesian basins in southwestern Idaho and southeastern Oregon: U.S. Geological Survey Water-Supply Paper 78, 53 p.

Sparlin, M.A., Braile, L.W., and Smith, R.B., 1982, Crustal structure of the eastern Snake River Plain determined from ray trace modeling of seismic refraction data: Journal of Geophysical Research, v. 87, no. 4, p. 2619-2633.

Stearns, H.T., and Bryan, L.L., 1925, Preliminary report on the geology and water resources of the Mud Lake basin, Idaho: U.S. Geological Survey Water-Supply Paper 560-D, 51 p.

Stearns, H.T., Bryan, L.L., and Crandall, Lynn, 1939, Geology and water resources of the Mud Lake region, Idaho, including the Island Park area: U.S. Geological Survey WaterSupply Paper 818, 125 p.

Stearns, H.T., Crandall, Lynn, and Steward, W.G., 1938, Geology and ground-water resources of the Snake River Plain in southeastern Idaho: U.S. Geological Survey Water-Supply Paper 774, 268 p.

Stewart, J.H., and Carlson, J.E., 1978, Geologic map of Nevada: U.S. Geological Survey Miscellaneous Field Studies Map MF-930, scale 1:500,000.

Stokes, W.L., 1963, Geologic map of Utah, northwest section: Utah State Land Board, scale 1:250,000.

Talwani, Manik, Worzel, J.L., and Landisman, Mark, 1959, Rapid gravity computations for two-dimensional bodies with application to the Mendocino submarine fracture zone: Journal of Geophysical Research, v. 64, p. 49-59.

Theis, C.V., Brown, R.H., and Meyer, R.R., 1963, Estimating the transmissibility of aquifers from specific capacity of wells, in Bentall, Ray, Methods of determining permeability, transmissibility, and drawdown: U.S. Geological Survey Water-Supply Paper 1536-I, p. 331-341.

Trimble, D.E., 1976, Geology of the Michaud and Pocatello quadrangles, Bannock and Power Counties, Idaho: U.S. Geological Survey Bulletin 1400, 88 p.

Walker, G.W., 1977, Geologic map of Oregon east of the 121st meridian: U.S. Geological Survey Miscellaneous Investiga- tions Map I-902, scale 1:500,000, 2 sheets.

Whitehead, R.L., 1978, Water resources of the upper Henrys Fork basin in eastern Idaho: Idaho Department of Water Resources, Water Information Bulletin 46, $91 \mathrm{p}$.

1986a, Compilation of selected geophysical references for the Snake River Plain, Idaho and eastern Oregon: U.S. Geological Survey Geophysical Investigations Map GP-969, scale $1: 1,000,000$.

1986b, Geohydrologic framework of the Snake River Plain, Idaho and eastern Oregon: U.S. Geological Survey Hydrologic Investigations Atlas HA-681, scale 1:1,000,000, 3 sheets.

Whitehead, R.L., and Lindholm, G.F., 1984, Results of geohydrologic test drilling in the eastern Snake River Plain, Gooding County, Idaho: U.S. Geological Survey WaterResources Investigations Report 84-4294, $30 \mathrm{p}$

Wood, S.H., and Anderson, J.E., 1981, Chapter 2 of Geology, Mitchell, J.C., ed., Geothermal investigations in Idaho, part 11, Geological, hydrological, geochemical, and geophysical investigations of the Nampa-Caldwell and adjacent areas, southwestern Idaho: Idaho Department of Water Resources Water Information Bulletin 30, p. 9-31.

Zohdy, A.A.R., 1973, A computer program for the automatic interpretation of Schlumberger sounding curves over horizontally stratified media: U.S. Geological Survey Report PB-232 703, 25 p. [available from U.S. Department of Commerce, National Technical Information Service, Springfield, VA 22161].

1974, Electrical methods, in Zohdy, A.A.R., Eaton, G.P., and Mabey, D.R., Application of surface geophysics to ground-water investigations: U.S. Geological Survey Techniques of Water-Resources Investigations, chap. D1, book 2, p. 5-66.

Zohdy, A.A.R., Bisdorf, R.J., and Jackson, D.B., 1978, Simple total field and Schlumberger soundings near Sugar City, Idaho: U.S. Geological Survey Open-File Report 78-709, 101 p.

Zohdy, A.A.R., and Stanley, W.D., 1973, Preliminary interpretation of electrical sounding curves obtained across the Snake River Plain from Blackfoot to Arco, Idaho: U.S. Geological Survey Open-File Report, 3 p. 